\title{
Foraminiferal evidence for inner neritic deposition of Lower Cretaceous (Upper Aptian) radiolarian-rich black shales on the Western Australian margin
}

\author{
DAVID W. HAIG \\ School of Earth \& Geographical Sciences, The University of Western Australia, 35 Stirling Highway, Crawley 6009, Australia \\ (e-mail: dhaig@segs.uwa.edu.au).
}

\begin{abstract}
Diverse foraminifera, Lingula-like brachiopods and the geological setting indicate that Aptian radiolarian-rich black shales forming the Windalia Radiolarite were deposited at water depths probably less than $40 \mathrm{~m}$ in the Southern Carnarvon Basin. Elsewhere in Australia, coeval radiolarian-rich deposits are widespread in other western-margin basins and in vast interior basins. The organic-rich mudstones containing the radiolaria include the foraminiferal Ammobaculites Association, a sparse benthic macrofauna and kerogens of mainly terrestrial plant origin. The deposits suggest that there was substantial high-nutrient freshwater input into the epeiric seas as well as high levels of dissolved silica resulting from marine flooding of a mature silicate-rich landscape bordered on the eastern and western continental margins by large volcanic provinces. The widespread presence of organic-rich muds through the broad, shallow Southern Carnarvon Basin and through the coeval interior basins suggests that regional geomorphology controlled the distribution of eutrophic facies in the Australian Aptian rather than any global expansion of the oceanic oxygen minimum zone. The foraminiferal assemblage from the Windalia Radiolarite consists of calcareous hyaline benthic types (diverse Lagenida as well as abundant Lingulogavelinella, Epistomina and Coryphostoma) and organic-cemented agglutinated species (including common Ammobaculites humei, Haplophragmoides-Recurvoides spp., and Verneuilinoides howchini). Planktonic foraminifera are very rare and present only in the northern, more open part of the basin. J. Micropalaeontol. 24(1): 55-75, May 2005.
\end{abstract}

KEYWORDS: Aptian, Australia, depositional environment, foraminifera, Windalia Radiolarite

\section{INTRODUCTION}

The Aptian was characterized by significant marine biotic change, oceanic anoxic events, sea-level rise, widespread drowning of shallow carbonate platforms, large igneous provinces and climate change enhancing greenhouse conditions (Weissert et al., 1998; Aguado et al., 1999; Clarke \& Jenkyns, 1999; Gröcke et al., 1999; Jahren et al., 2001; Jones \& Jenkyns, 2001). In Australia, continent-wide marine flooding resulted in a vast shallow interior sea (Fig. 1) that stretched from the western and northern margins to the eastern interior of the continent (Frakes et al., 1987; Henderson et al. 2000). A large igneous province bounded the continent along its eastern margin and contributed significant sediment to the interior sea (Bryan et al., 1997) and the Kerguelen large igneous province had peak volcanic activity between $c .120$ to $c .95 \mathrm{Ma}$ (Coffin et al., 2002) off the western margin. The palaeogeographical development of the continent during the Aptian was influenced fundamentally by changes in hotspot magmatism (Coffin et al., 2002), plate motions (Veevers et al., 1991; Li \& Powell, 2001) and a broad trend of sea-level rise (Hardenbol et al., 1998).

The Aptian flooding was the first major marine inundation across the subdued landscape of the Australian continent since the Early Permian, and its sedimentary and biotic record is found in very uniform, mud-dominated successions that remain undeformed over most of the region. Among the shelled biota, macrofossils are generally rare, with common occurrences confined to isolated stratigraphic horizons and localities. Foraminifera are the most abundant and persistent shelled group in the Aptian of the interior sea (Crespin, 1963; Ludbrook, 1966; Scheibnerová, 1976; Haig, 1980, 1982; Campbell \& Haig, 1999). They characterize the Ammobaculites
Association (Haig, 1979a; Haig \& Lynch, 1993) and include abundant organic-cemented siliceous agglutinated types as well as diverse hyaline calcareous benthic species. In the interior-sea deposits, radiolarians and diatoms are also abundant, but their

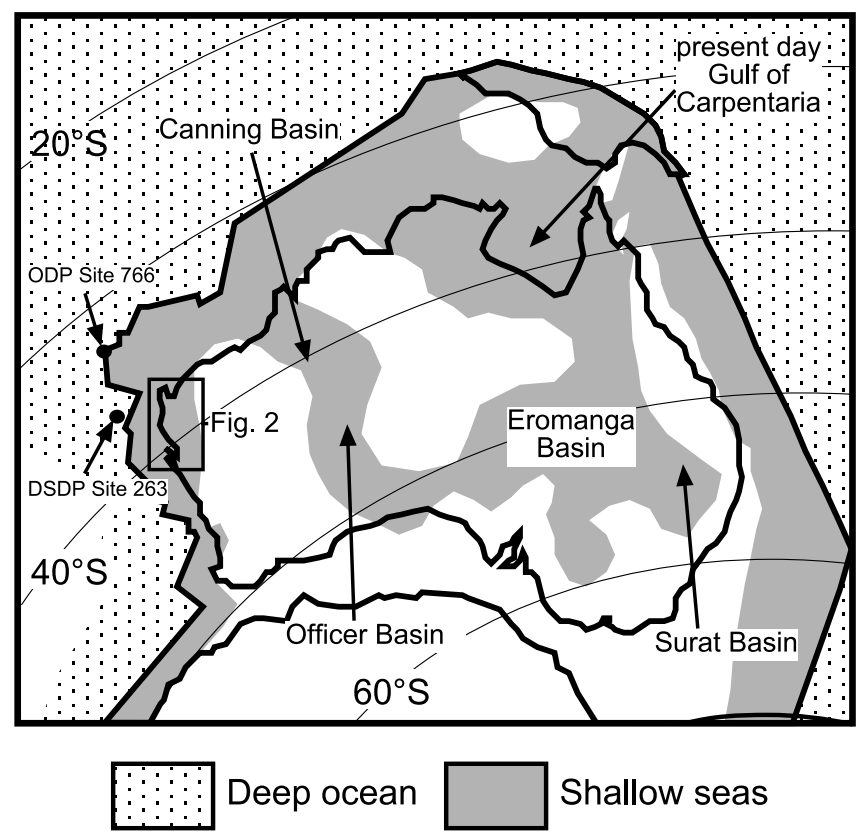

Fig. 1. Map of the Australian continent showing the extent of the Aptian sea. The insert box outlines the Southern Carnarvon Basin. Shoreline position follows Frakes et al. (1987) and palaeolatitudes follow Li \& Powell (2001) 
preservation is variable (Haig \& Barnbaum, 1978). On the western margin, Aptian deposits are mainly radiolarian-rich mudstones (Hocking et al., 1987; Ellis, 1993) that are often porcelanized in outcrop containing very few foraminifera and only sporadic macrofossils, mainly belemnites (Peratobelus) and ammonites (Australiceras, Tropaeum, Toxoceratoides and Acanoceras; Ellis, 1993). The radiolaria, although abundant, are usually very poorly preserved.

In the confined Surat Basin of eastern Australia (part of the interior sea, Fig. 1), Haig \& Barnbaum (1978) showed that radiolaria are abundant in Aptian deposits that accumulated at water depths too shallow for inward migration of planktonic foraminifera and calcareous nannoplankton. The laterally extensive strata that were deposited in the interior sea and are preserved in flat-lying successions suggest that the sea-floor gradient was very gentle and water depths were probably equivalent to those in the present-day Gulf of Carpentaria (Fig. 1), probably less than $60 \mathrm{~m}$ deep over most of the region (Haig \& Lynch, 1993; Campbell \& Haig, 1999; Haig, 2004).

This paper investigates the palaeobathymetry of the radiolarian-rich mudstones that comprise the Windalia Radiolarite in the Southern Carnarvon Basin on the western continental margin (Fig. 2). Equivalent radiolarian-rich formations of Aptian age have been recorded from other basins along this margin and in the adjacent Canning and Officer basins of Western Australia, but are less well known. Apart from general stratigraphic accounts (Condon, 1968; Hocking et al., 1987), very little information has been published on the Windalia Radiolarite, particularly about its type area in the Southern Carnarvon Basin. Ellis (1993) documented the radiolarian fauna from the type section and inferred a neritic water depth based on basin setting rather than on the poorly known radiolarian assemblages. No foraminifera were recovered from the type section and very few have been found in other outcrop sections of the formation in the basin. Recent boreholes (Table 1) in the Southern Carnarvon Basin provide continuously cored sections (Fig. 3) through the Windalia Radiolarite and the underlying and overlying units that collectively form the Winning Group. The recovery of well-preserved foraminiferal assemblages from these sections allows more detailed palaeobathymetric trends to be interpreted for the formation.

\section{BASIN SETTING}

The basin setting (Fig. 2) places limitations on possible interpretations of depositional water depth. The Cretaceous strata of the Southern Carnarvon Basin form a flat-lying veneer on Palaeozoic deposits and have been subjected to very little burial (Iasky et al., 1998, 2003). The Windalia Radiolarite is part of the Winning Group that, in the Southern Carnarvon Basin, ranges from the Barremian to Cenomanian and is distinguished by its siliciclastic mud composition from the overlying pelagic carbonate deposits of the later Cretaceous. The stratigraphic succession within the Winning Group is summarized in Figure 4. The Windalia Radiolarite is lithologically uniform in the subsurface, characterized by dark-grey mudstone with a variable abundance of radiolaria (comprising greater than $50 \%$ of the rock in some beds; Hocking et al., 1987). Total organic carbon values for the few samples analysed from the studied sections range from $1.70 \%$ to $2.91 \%$, with kerogens in the Type III category (Mory \&

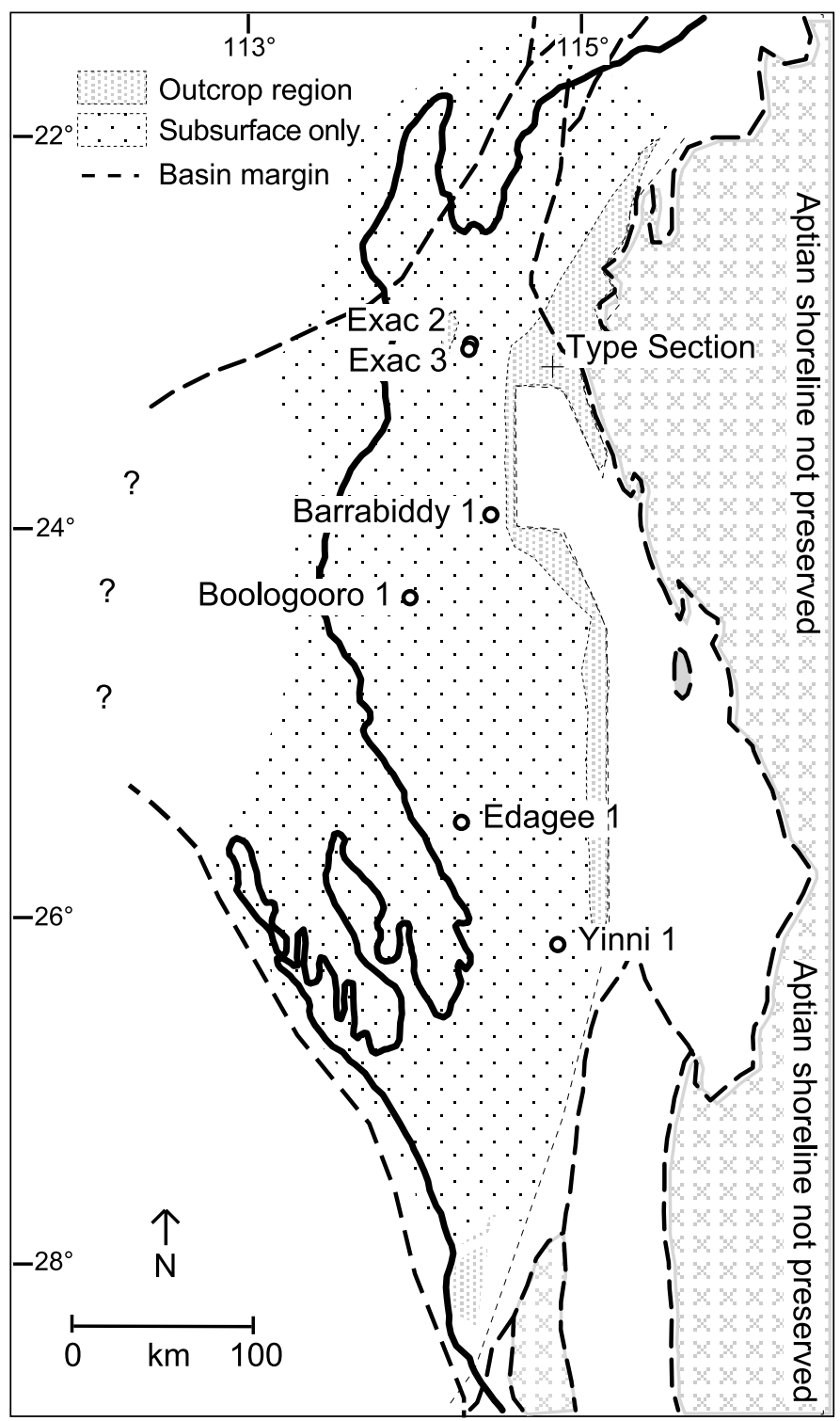

Fig. 2. Map of Southern Carnarvon Basin showing outcrop and subsurface extent of the Windalia Radiolarite and location of studied boresections. The position of the type section of the formation is also shown.

Yasin, 1999; Dixon et al., 2003a, b), indicating a mainly terrestrial plant source (Tyson, 1987). The formation is silicified in some sections (e.g. Edaggee 1; Fig. 3) but friable in others (e.g. most of Yinni 1, Barrabiddy 1, Exac 2 and 3; Fig. 3). Formation thickness increases northwards (for example from $22 \mathrm{~m}$ in Yinni 1 to $83 \mathrm{~m}$ in Exac 3). Along the eastern margin of the basin, the formation has been eroded and coeval shoreline sand facies are not represented. The Cretaceous strata undoubtedly extended across the Precambrian basement to the east of the present basin margin (Fig. 2), where they have been removed by erosion. Throughout the basin, almost all of the formation, including the studied sections, lies within the Diconodinium davidii Dinoflagellate Zone (based on continuing work by J. Backhouse, and his published determinations in Mory \& Yasin (1999) and Dixon et al. (2003a, b)). Based on the presence of 
Aptian foraminifera from neritic radiolarite

\begin{tabular}{lcll}
\hline Borehole & Latitude & Longitude & \multicolumn{1}{c}{ Well completion reports references } \\
\hline Yinni 1 & $26^{\circ} 03^{\prime} 22.8^{\prime \prime} \mathrm{S}$ & $114^{\circ} 48^{\prime} 58.5^{\prime \prime} \mathrm{E}$ & Mory \& Dixon (2002a), Dixon et al. (2003a) \\
Edaggee 1 & $25^{\circ} 21^{\prime} 27.0^{\prime \prime} \mathrm{S}$ & $114^{\circ} 14^{\prime} 04.9^{\prime \prime} \mathrm{E}$ & Mory \& Dixon (2002c), Dixon et al. (2003b) \\
Boologooro 1 & $24^{\circ} 19^{\prime} 27.3^{\prime \prime} \mathrm{S}$ & $113^{\circ} 53^{\prime} 53.3^{\prime \prime} \mathrm{E}$ & Mory \& Dixon (2002b), Haig et al. (2004) \\
Barrabiddy 1 & $23^{\circ} 49^{\prime} 57.0^{\prime \prime} \mathrm{S}$ & $114^{\circ} 20^{\prime} 00.0^{\prime \prime} \mathrm{E}$ & Mory \& Yasin (1999) \\
Exac 3 & $23^{\circ} 06^{\prime} 21.0^{\prime \prime} \mathrm{S}$ & $114^{\circ} 10^{\prime} 14.7^{\prime \prime} \mathrm{E}$ & unavailable (drilled by ASARCO Exploration Company 2003) \\
Exac 2 & $23^{\circ} 04^{\prime} 25.8^{\prime \prime} \mathrm{S}$ & $114^{\circ} 10^{\prime} 07.7^{\prime \prime} \mathrm{E}$ & unavailable (drilled by ASARCO Exploration Company 2003) \\
\hline
\end{tabular}

Table 1. Studied wells

\section{South}

North

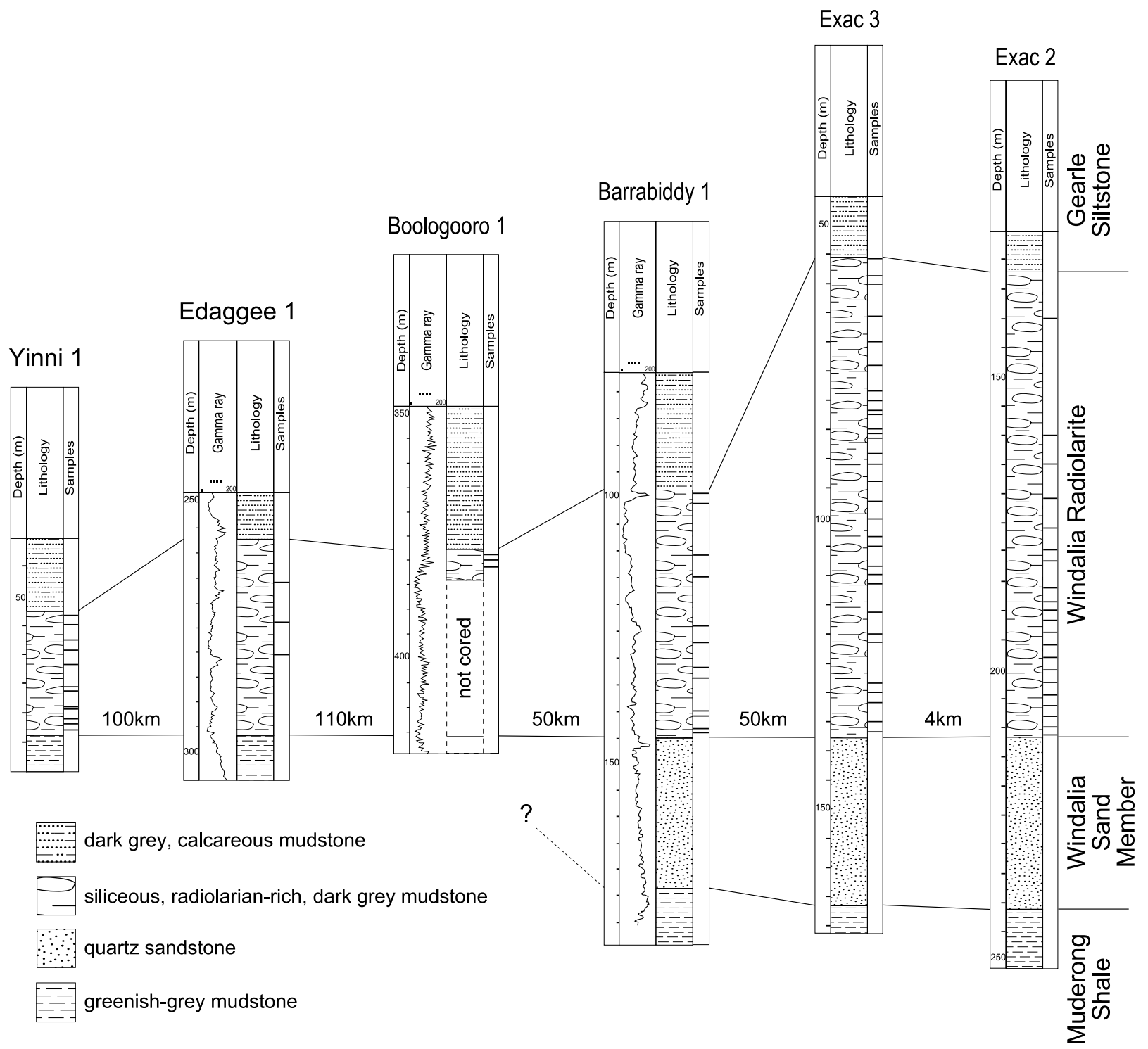

Fig. 3. South-north stratigraphic cross-section showing studied boresections and the sample coverage. The formations represented in the cross-section are indicated on the right-hand side. The Windalia Sand Member is the uppermost member of the Muderong Shale.

ammonites and belemnites in outcrop and on Australian dinoflagellate and foraminiferal correlations, most of the Windalia Radiolarite belongs to the Upper Aptian, although the uppermost part of the formation may be lowest Albian (Dixon et al., 2003a, b).
The Windalia Radiolarite was deposited on a continental platform adjacent to a passive margin that formed by rifting of Greater India from Australia during the Valanginian at about 130-136 Ma (Müller et al., 1998). The studied sections are positioned at least $200 \mathrm{~km}$ from the continent-ocean margin. 


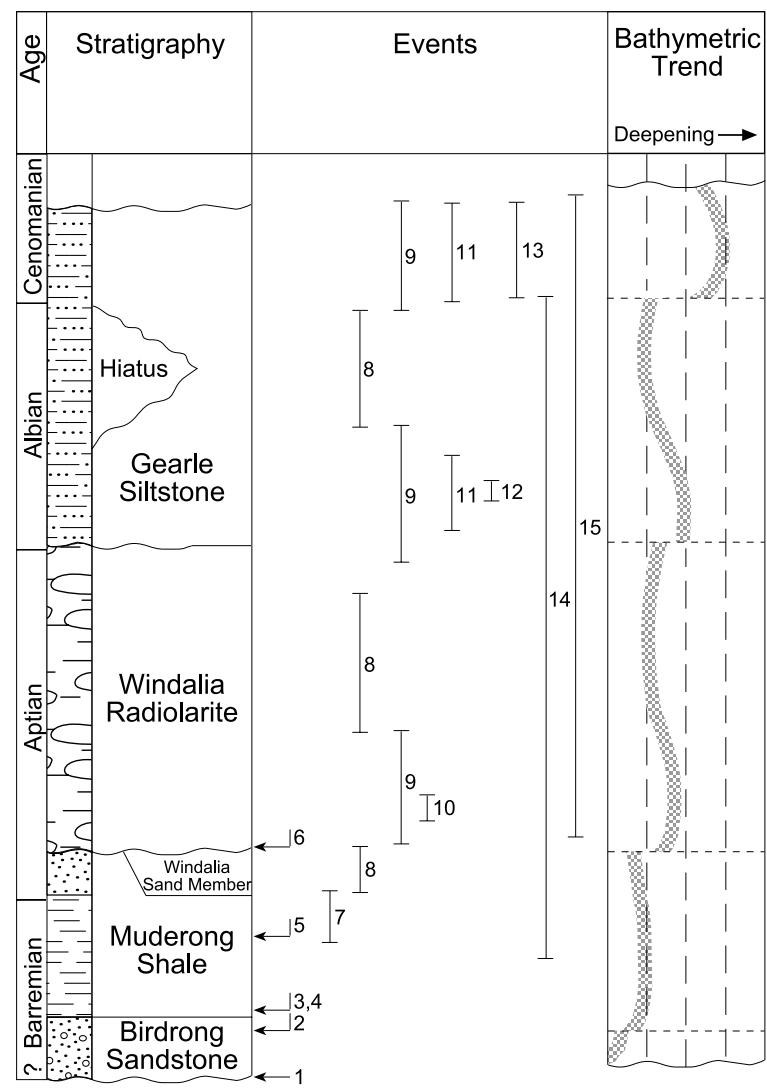

1. Start of Cretaceous marine transgession

2. Lowest occurrence of organic-cemented agglutinated foraminifera

3. Lowest occurrence of diatom frustules (pyritized)

4. Lowest occurrence of sponge spicules (opaline silica)

5 . Lowest occurrence of radiolarians (pyritized)

6 . Lowest occurrence of calcareous hyaline benthic foraminifera

7. Calcareous foraminifera may have dissolved from pyrite-rich mudstone

8. Rare foraminifera (only organic-cemented agglutinated types)

8. Rare foraminifera (only organic-cemented agglutinated types)
9. Diverse and abundant calcareous hyaline benthic foraminifera

10. Rare planktonic foraminifera (much less than $1 \%$ of total assemblage)

11. Common planktonic foraminifera ( $<5 \%$ of total assemblage)

12. One species of calcite-cemented agglutinated foraminifera

13. Diverse abundant calcite-cemented agglutinated foraminifera

14. Lingula - like brachiopods common

15. Belemnites and ammonites sporadic

Fig. 4. Schematic outline of the stratigraphic succession in the Winning Group showing major events related to bathymetric trends. Stipple patterns as in Figure 3.

The almost horizontal attitude of bedding and the distribution of uniform facies over a vast area (Fig. 2) suggest that the sea-floor gradient on the platform was very gentle during deposition of the Windalia Radiolarite and implies that no deep topographic basin formed during the Aptian in this region. However, facies transitions toward the west over the adjacent continent-ocean margin cannot be determined at present because of a lack of boreholes and detailed seismic coverage. It is possible that the continental margin was slightly elevated during the Aptian as it was the site of substantial igneous activity during the earlier Cretaceous (Symonds et al. 1998).

The Windalia Radiolarite is part of the Barremian to Cenomanian Winning Group (Fig. 4), which appears to include five main depositional cycles that coincide with formations: (1) the Barremian (possibly ranging from Late Hauterivian) Birdrong Sandstone; (2) the Barremian to Early Aptian
Muderong Shale with the Windalia Sand Member at top; (3) the Late Aptian Windalia Radiolarite; (4) the Albian part of the Gearle Siltstone; and (5) the Cenomanian part of the Gearle Siltstone. Despite the formation name, the Gearle Siltstone is mainly a mudstone that is radiolarian-rich and glauconitic at some levels. The general lithological and biostratigraphic succession suggests an overall retrogradational trend with successive formations (= sequences) reflecting deeper-water conditions at successive maximum marine-flooding events. Maximum flooding seems to be represented in the lower part of each sequence with the upper part of each cycle being slightly progradational. In the overall depositional trend, the Windalia Radiolarite seems transitional between a shallower-water Muderong Shale and a deeper-water Gearle Siltstone.

\section{MATERIAL AND METHODS}

Core samples from six borehole sections (Table 1; Fig. 3), located along an approximate $300 \mathrm{~km}$ north-south transect of the basin (Fig. 2), form the basis of this study. Exac 2 and 3, Barrabiddy 1 and Yinni 1 provide the most detailed coverage through the formation. Most of the Edaggee 1 section is silicified mudstone unsuitable for foraminiferal extraction and Boologooro 1 includes only the uppermost few metres of the Windalia Radiolarite.

Friable mudstone samples were disaggregated by boiling in water with added detergent and Calgon ${ }^{\mathrm{TM}}$ and were wet-sieved on $63 \mu \mathrm{m}$ and $150 \mu \mathrm{m}$ meshes. All residues were picked comprehensively. Because of variable preservation, particularly among the organic-cemented agglutinated species, species abundances are recorded semi-quantitatively as rare $(<10$ specimens), common (10-20 specimens) or abundant ( $>20$ specimens). For each sample, the entire $>150 \mu \mathrm{m}$ residue was picked of foraminifera and four $42 \mathrm{~cm}^{2}$ trays of the $63-150 \mu \mathrm{m}$ fraction were also picked. Figured specimens are housed in the micropalaeontological collections of the School of Earth and Geographical Sciences, The University of Western Australia.

\section{GENERAL FAUNAL DISTRIBUTION}

Table 2 records the composition of the sand residues washed from the carbonaceous mudstone samples. A much more varied taxonomic assemblage is present among the biogenic grains than suggested by macrofossils observed in the core. Besides radiolaria and foraminifera, the biota that contributed skeletal sand-size material to the sediment includes diatoms, sponges, Lingula-like brachiopods, bivalves, gastropods, ammonites, belemnites, echinoids, ostracods, scolecodonts and fish. Both benthic and nektonic animals are represented and at only a few levels in the formation are skeletons of benthic organisms absent.

Well-preserved radiolarian tests were extracted from few samples. In many samples, particularly from Exac 2 and 3, recrystallized radiolarian skeletons apparently disaggregated during washing, and in other samples the tests had been replaced by pyrite or glauconite. Where present, the hyaline calcareous foraminifera are well preserved (Plates 1-4). Most species belong to the Order Lagenida, but abundant representatives of the Robertinida (with aragonitic tests), Buliminida and Rotaliida 


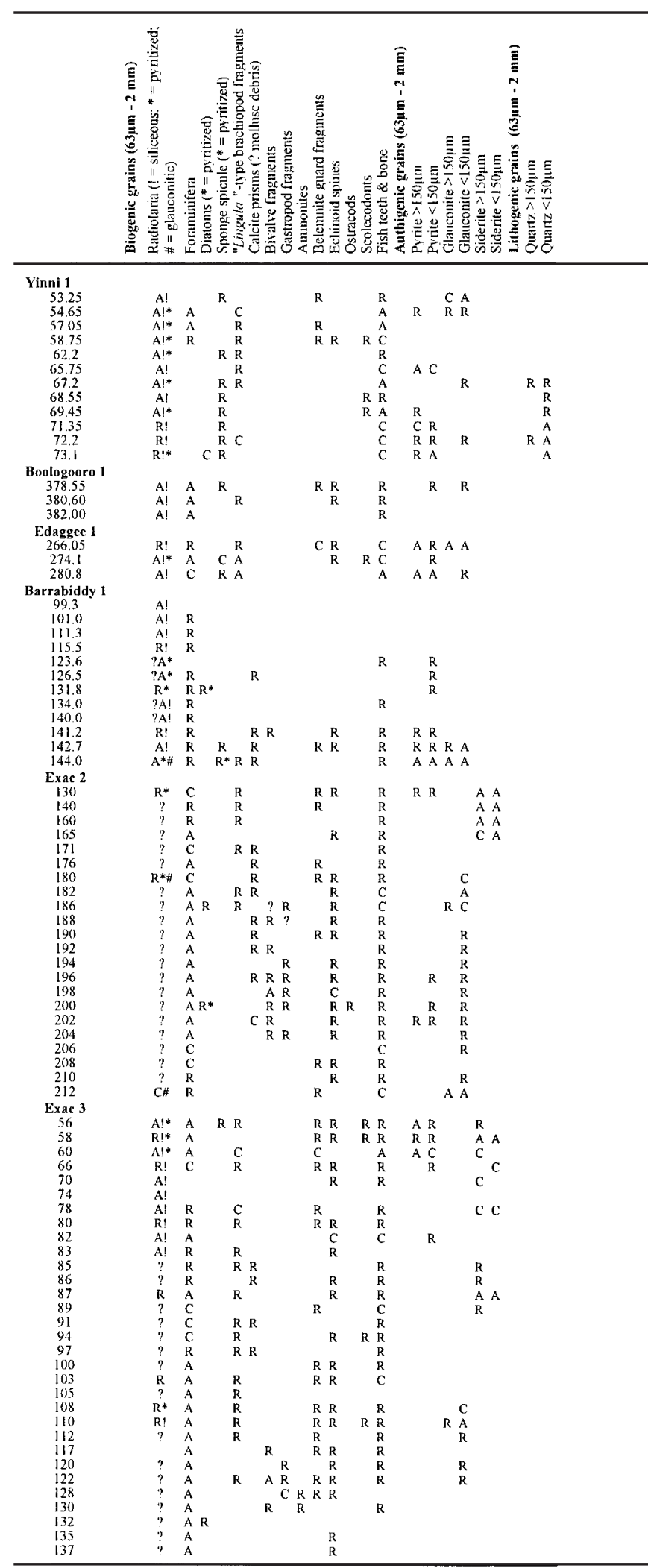

A, abundant; C, common; $\mathrm{R}$, rare.

Table 2. Biogenic, authigenic and lithogenic constituents of sand fractions in studied samples are also present. Spirillinids are very rare. The siliceous agglutinated foraminifera are usually deflated and distorted. In these tests, original siliceous grains (mainly quartz) were held together by organic cement forming a flexible test, as in modern Trochammina. After burial, diagenetic quartz overgrowths on the agglutinated grains apparently produced the rigid fossil tests. Silicification of original calcareous material has not occurred. Calcite-cemented agglutinated taxa are absent. Almost all of the foraminifera are benthic types and their distributions are recorded on Figures 5-10. Planktonic foraminiferal tests of the Order Globigerinida have been recovered only from restricted levels in the northern sections (namely Exac 2 and 3, and Barrabiddy 1; Figs 7-10) where they form much less than $1 \%$ of the foraminiferal assemblage.

\section{SIGNIFICANCE OF FORAMINIFERAL DISTRIBUTIONS}

Within the Windalia Radiolarite, foraminiferal distributions in Barrabiddy 1, Exac 2 and 3 show a similar pattern (Figs 8-10). The lower part of the formation (126-144 $\mathrm{m}$ in Barrabiddy 1; 176-210 $\mathrm{m}$ in Exac 2; and 80-137 $\mathrm{m}$ in Exac 3) contains a diverse benthic foraminiferal assemblage, above which is a zone with reduced foraminiferal diversity and abundance including some barren intervals. Planktonic foraminifera occur in the lower unit in all these holes, but only in a restricted interval (141-143 $\mathrm{m}$ in Barrabiddy 1; 196-204 $\mathrm{m}$ in Exac 2; and 120-132 $\mathrm{m}$ in Exac 3). In Yinni 1, the formation is much thinner than in the other boreholes and the lower $14 \mathrm{~m}$ is barren of foraminifera. This interval is the only section studied from the Windalia Radiolarite where quartz is present in the sand fraction (decreasing in abundance up section; Table 2). A diverse benthic foraminiferal assemblage similar in composition to that in the lower unit in the northern holes is present in Yinni 1 in the 54-58 $\mathrm{m}$ interval (Fig. 5). However, planktonic foraminifera are absent. Dinoflagellates suggest that the 54-58 m interval correlates to part of the lower unit of the formation in Barrabiddy 1 and Exac 3 (J. Backhouse pers. comm., November 2003). The upper unit of the Windalia Radiolarite may be missing from Yinni 1. In Exac $3(56-60 \mathrm{~m})$ the uppermost Windalia Radiolarite contains a foraminiferal assemblage that includes abundant agglutinated types and some common hyaline calcareous benthic species (Fig. 9) and rare very poorly preserved planktonic foraminifera. Similarly, the uppermost Windalia Radiolarite in Boologooro 1 contains abundant calcareous hyaline benthic foraminifera (Fig. 7). The foraminiferal distribution patterns parallel changes observed in the dinoflagellate assemblages (Backhouse, 2004) suggesting that the distributions reflect environmental changes rather than being the result of selective carbonate dissolution.

Maximum flooding during deposition of the Windalia Radiolarite is probably marked by the presence of planktonic foraminifera associated with diverse hyaline benthic types in Exac 2 (196-204 m), Exac 3 (120-132 m) and Barrabiddy 1 (141-143 m) and, more generally, by the presence of abundant calcareous hyaline benthic foraminifera in Yinni 1 (54-58 m). The characteristics of the fauna that lead to palaeobathymetric interpretation include: (1) planktonic foraminifera become more common toward the north, but there represent much less than $1 \%$ of the total foraminiferal assemblage; (2) the benthic assemblage is dominated by calcareous hyaline types, and especially 


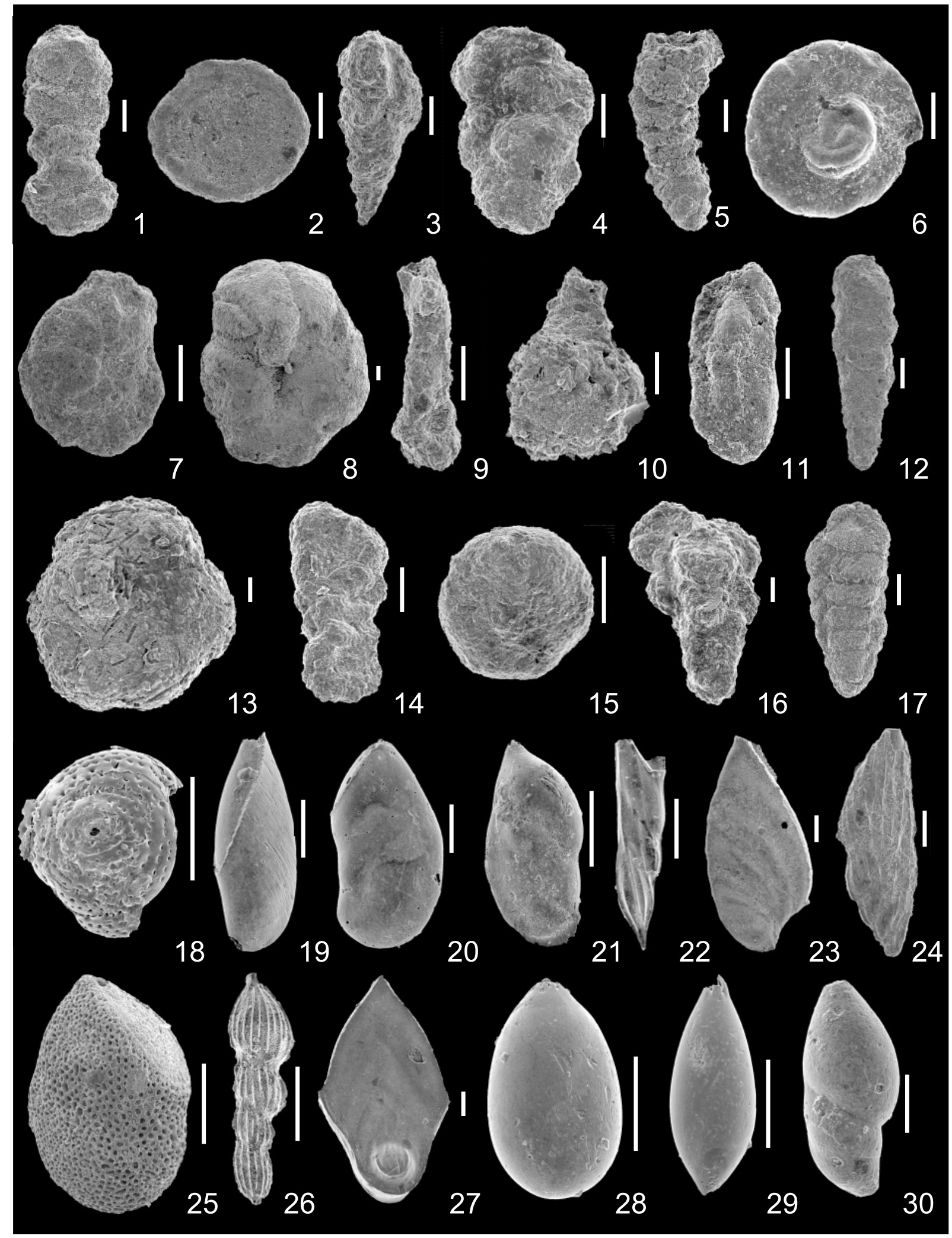


by Lingulogavelinella spp., Epistomina chapmani, Coryphostoma sp. and diverse species of the Order Lageniida (including large Lenticulina and Planularia). The accompanying agglutinated species are organic-cemented types including common Ammobaculites humei, Haplophragmoides-Recurvoides spp. and Verneuilinoides howchini.

Assessment of depositional water depth depends on comparisons to modern marine facies and by deductions derived based on the basin setting and the succession of facies both in a local stratigraphic sense and in a regional perspective. In order to gain an appreciation of the water depth at the time of maximum flooding, the fauna marking this event is compared with (1) that from maximum flooding events in sequences stratigraphically above and below the Windalia Radiolarite in the basin; (2) faunas from different facies of similar age in the Australian region; and (3) Cretaceous bathymetric models derived from foraminiferal distributions on other continents.

\section{Comparison with adjacent sequences}

The foraminiferal fauna from the underlying Muderong Shale (Barremian) in the Southern Carnarvon Basin is composed almost entirely of organic-cemented agglutinated species (Taylor \& Haig, 2001; Dixon et al., 2003a, b). Rare calcareous hyaline benthic forms (Lenticulina spp.) are present at a few levels and may have been dissolved in pyritic muds at other levels. For the same volume of sediment, the agglutinated foraminifera are more abundant in the Muderong Shale than in the Windalia Radiolarite. Most of the common agglutinated species in the Windalia Radiolarite are also represented in the Muderong Shale. However, some rare Windalia types (Portatrochammina? sp., Gaudryinopsis filiformis and Glomospirella gaultina) have not been recorded from the underlying sequence. Among other fossils, very small Lingula-like brachiopods occur through the Muderong Shale and the Windalia Radiolarite (Dixon et al., 2003a, b). Belemnite guards, present in the Windalia Radiolarite, are absent from the Muderong Shale.

The Muderong Shale was probably deposited under inner neritic conditions in a restricted sea (Taylor \& Haig, 2001).
Based on faunal differences outlined above, maximum flooding during deposition of the Windalia Radiolarite seems to have involved slightly deeper-water conditions. During the Late Aptian the sea may have been more open to circulation from the open ocean as suggested by the presence of belemnites and planktonic foraminifera and the diverse calcareous hyaline benthic assemblage. The bathymetric trend towards shallower conditions to the south that Taylor \& Haig (2001) identified for the Barremian, may have been present also during the Late Aptian, as suggested by the more common occurrence of planktonic foraminifera in the north.

Foraminifera from the overlying lower part of the Gearle Siltstone (Albian) include planktonic foraminifera that are more common than in the Windalia Radiolarite, but still form less than $5 \%$ of the total foraminiferal assemblage (Haig et al., 1996; Dixon et al., 2003a, b; Haig et al., 2004). As in the lower Windalia Radiolarite, the lower Gearle Siltstone contains diverse calcareous hyaline benthic species, with common to abundant Lingulogavelinella, Coryphostoma, Epistomina and a diverse collection of Lagenida. Berthelina intermedia and small Pleurostomella reussi appear in the Lower Albian beds and Lingulogavelinella santoodnae and related species are rare. The organic-cemented agglutinated assemblage from the lower Gearle Siltstone contains similar species to those in the Windalia Radiolarite, but Gaudryinopsis filiformis generally becomes abundant and Verneuilinoides howchini is rare. The lowest occurrence of calcite-cemented agglutinated foraminifera (Spiroplectinata? sp. of Haig et al., 1996) in the basin succession is in the lower Gearle Siltstone. As in the Windalia Radiolarite, belemnites and Lingula-like brachiopods are present in the lower Gearle Siltstone.

The presence of Lingula-like brachiopods in the Muderong Shale, Windalia Radiolarite and parts of the Gearle Siltstone (Dixon et al., 2003a, b) suggests deposition in upper subtidal conditions, probably at water depths above $40 \mathrm{~m}$ (following the modern bathymetric range of Lingula, as summarized by Ferguson, 1963). The modern types are abundant in organicrich muds, at temperatures greater than $10^{\circ} \mathrm{C}$ and in salinities

\section{Explanation of Plate 1.}

Secondary electron images; bar scale $0.1 \mathrm{~mm}$. fig. 1. Ammobaculites humei Nauss, 1947, from Exac 3 at 94 m, UWA133938 (lateral view). fig. 2. Ammodiscus glabratus Cushman \& Jarvis, 1928, from Edaggee 1 at $274.1 \mathrm{~m}$, UWA133939 (lateral view). fig. 3. Bimonilina sp. from Barrabiddy 1 at 144 m, UWA133940 (lateral view). fig. 4. Gaudryinella sherlocki Bettenstaedt, 1952, from Exac 3 at 120 m, UWA133941 (lateral view). fig. 5. Gaudryinopsis filiformis (Berthelin, 1880) from Exac 2 at 171 m, UWA133942 (lateral view). fig. 6. Glomospirella gaultina (Berthelin, 1880) from Exac 3 at 56 m, UWA133943 (lateral view). fig. 7. Haplophragmoides sp. cf. H. minor Nauss, 1947, from Edaggee 1 at 274.1 m, UWA133944 (lateral view). fig. 8. Haplophragmoides sp. from Barrabiddy 1 at $126.5 \mathrm{~m}$, UWA133945 (lateral view). fig. 9. Hyperammina gaultina ten Dam, 1950, from Barrabiddy 1 at $142.7 \mathrm{~m}$, UWA133946 (lateral view). fig. 10. Lagenammina alexanderi (Loeblich \& Tappan, 1950) from Exac 2 at $200 \mathrm{~m}$, UWA133947 (lateral view). fig. 11. Miliammina ischnia Tappan, 1957, from Exac 2 at $196 \mathrm{~m}$, UWA133948 (lateral view). fig. 12. Palustrella sp. from Exac 3 at 94 m, UWA133949 (lateral view). fig. 13. Portatrochammina? sp. from Exac 2 at 188 m, UWA133950 (lateral view). fig. 14. Spiroplectammina edgelli Crespin, 1953, from Exac 3 at 91 m, UWA133951 (lateral view). fig. 15. Thuramminoides laevigata White, 1928, from Barrabiddy 1 at $131.8 \mathrm{~m}$, UWA133952 (lateral view). fig. 16. Verneuilinoides howchini (Crespin, 1953) from Exac 3 at $122 \mathrm{~m}$, UWA133953 (lateral view). fig. 17. Verneuilinoides neocomiensis (Myatliuk, 1939): from Exac 2 at $202 \mathrm{~m}$, UWA133954 (lateral view). fig. 18. Patellinoides tilchus (Ludbrook, 1966) from Exac 2 at 198 m, UWA133955 (spiral view). fig. 19. Astacolus calliopsis (Reuss, 1863) from Barrabiddy 1 at 142.7 m, UWA133956 (lateral view). fig. 20. Astacolus sp. cf. A. howchini Ludbrook, 1966, from Barrabiddy 1 at 142.7 m, UWA133957 (lateral view). fig. 21. Astacolus sp. 1: from Barrabiddy 1 at 142.7 m, UWA133958 (lateral view). fig. 22. Brunsvigella debilis (Berthelin, 1880) from Exac 2 at 198 m, UWA133959 (lateral view). fig. 23. Citharina tyelea Ludbrook, 1966, from Yinni 1 at 57.05 m, UWA133960 (lateral view). fig. 24. Citharina sp. from Boologooro $1382.0 \mathrm{~m}$, UWA133961 (lateral view). fig. 25. Cristellariopsis pristipellis (Ludbrook, 1966) from Yinni 1 at 57.05 m, UWA133962 (lateral view). fig. 26. Dentalina sp. from Exac 2 at 198 m, UWA133963 (lateral view). fig. 27. Frondicularia sp. cf. F. filocincta Reuss, 1863, from Exac 3 at 117 m, UWA133964 (lateral view). fig. 28. Globulina lacrima Reuss, 1845, from Exac 2 at 196 m, UWA133965 (lateral view). fig. 29. Globulina prisca Reuss, 1863, from Yinni 1 at 54.65 m, UWA133966 (lateral view). fig. 30. Hemirobulina hamulus (Chapman, 1894) from Boologooro 1 at $382.0 \mathrm{~m}$, UWA133967 (lateral view). 


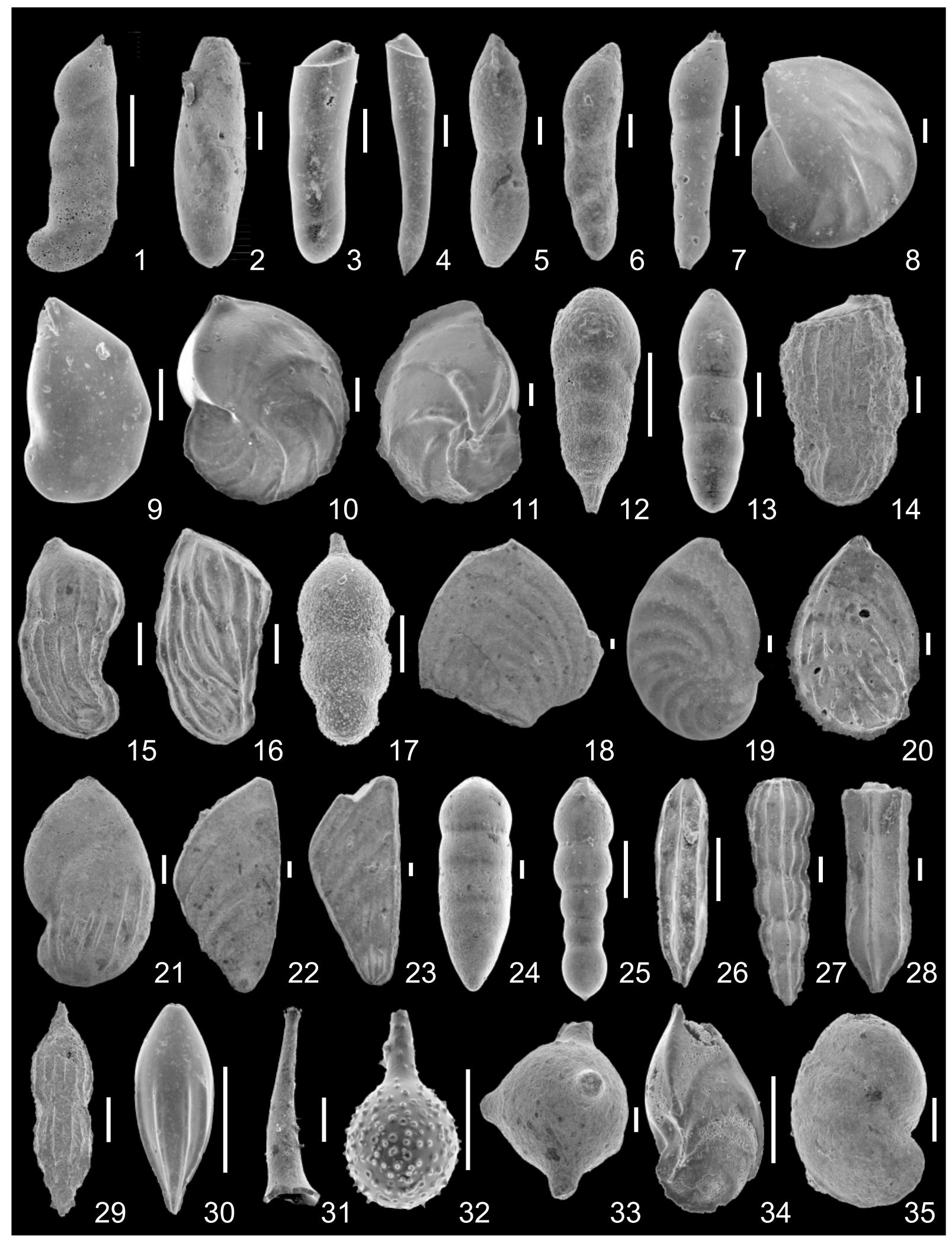


that range from brackish to normal (Ferguson, 1963). Based on oxygen isotope analyses of belemnite guards from the lower Gearle Siltstone (from the locality described by Haig et al., 1996), Pirrie et al. (1995) suggested that the water temperature during the Early Albian was about $15^{\circ} \mathrm{C}$. A sea-surface maximum palaeotemperature for the Late Aptian of $12^{\circ} \mathrm{C}$ was determined by Clarke \& Jenkyns (1999) from Exmouth Plateau (Fig. 1), and for the Early Albian of about $15^{\circ} \mathrm{C}$.

The more common planktonic foraminifera, the presence of abundant Berthelina and greater diversity of Lingulogavelinella and the first appearance of calcite-cemented agglutinated species suggest that the maximum flooding during lower Gearle Siltstone deposition was deeper than during deposition of the Windalia Radiolarite. Therefore, the foraminiferal succession indicates that the Windalia Radiolarite formed part of a marine transgressive trend intermediate between the shallower-water Muderong Shale and the deeper-water Gearle Siltstone. The very rare occurrence of planktonic foraminifera in the Windalia Radiolarite is consistent with the inner neritic ( $<40 \mathrm{~m}$ deep) water depth suggested by the Lingula-like brachiopods.

\section{Comparison with coeval Australian faunas}

Elsewhere in Australia, Upper Aptian foraminifera are well documented from the Eromanga, Surat and Carpentaria basins (Crespin, 1963; Ludbrook, 1966; Scheibnerová, 1976; Haig, 1980, 1982; Campbell \& Haig, 1999) and from the continental margin in ODP Hole 766 (Haig, 1992; Holbourn \& Kaminski, 1997). In terms of composition, the Windalia Radiolarite assemblages are closer to the interior-basin faunas than to those from the continental margin (Henderson et al., 2000). The former belong to Haig's (1979a) Ammobaculites Association, whereas the latter are part of the Marssonella Association.

Based on foraminiferal assemblages, the Windalia Radiolarite correlates to the upper sequence recognized by Campbell \& Haig (1999) in the Doncaster Member of the Eromanga
Basin. The correlation is based on two evolutionary lineages that Haig (1982) recognized among the calcareous hyaline benthic foraminifera: the overlap in ranges of Turrilina? hergottensis and its descendant T? moorei, and the overlap of Lingulogavelinella sp. cf. L. albiensis and its descendant $L$. santoodnae.

Of the three foraminiferal biofacies that Haig (1979b) recognized in the Ammobaculites Association, the 'Lingulogavelinella albiensis biofacies' best characterizes the Windalia Radiolarite. In the interior basins, this biofacies is intermediate between the shallower 'Ammobaculites australis biofacies' and the deeper 'Neobulimina albertensis biofacies'. Campbell \& Haig (1999) distinguished seven biofacies in their detailed analysis of the Aptian to Lower Albian succession in the northeast Eromanga Basin. The assemblages that indicate maximum-flooding in the Windalia Radiolarite are similar to those that characterize Biofacies 4 (mid offshore to upper offshore) of Campbell \& Haig (1999), and those assemblages in the northern wells containing the rare planktonic foraminifera are representative of Biofacies 5 (mid offshore). These correlations suggest that the maximum flooding in the Windalia Radiolarite peaked in the deep part of the inner neritic zone (equivalent to mid offshore in the interior sea described by Campbell \& Haig, 1999).

The coeval continental margin fauna from ODP Site 766 (cores 24 and 25; Haig, 1992) is dominated by planktonic foraminifera and includes calcite-cemented agglutinated species with no organic-cemented siliceous types, abundant Berthelina (referred to Gavelinella by Haig, 1992) and abundant medium to large-size Gyroidinoides (in contrast to the rare minute types of this genus found in the Windalia Radiolarite). The continental margin fauna belongs to the Marssonella Association (as defined by Haig, 1979a) and clearly lived in much deeper water than did the foraminifera from the Windalia Radiolarite and the interior seas.

\section{Explanation of Plate 2.}

Secondary electron images; bar scale $0.1 \mathrm{~mm}$. fig. 1. Hemirobulina linearis (Reuss, 1863), from Barrabiddy 1 at 142.7 m, UWA1333968 (lateral view). fig. 2. Hemirobulina sp., from Barrabiddy 1 at $142.7 \mathrm{~m}$, UWA133969 (lateral view). fig. 3. Laevidentalina hamiltonensis (Ludbrook, 1966), from Barrabiddy 1 at 142.7 m, UWA133970 (lateral view). fig. 4. Laevidentalina luma (Belford, 1960), from Yinni 1 at 57.05 m, UWA133971 (lateral view). fig. 5. Laevidentalina oligostegia (Reuss, 1845), from Boologooro 1 at $380.6 \mathrm{~m}$, UWA133972 (lateral view). fig. 6. Laevidentalina nana (Reuss, 1863), from Boologooro 1 at 380.6 m, UWA133973 (lateral view). fig. 7. Laevidentalina sororia (Reuss, 1845), from Exac 3 at 117 m, UWA133974 (lateral view). fig. 8. Lenticulina muensteri (Roemer, 1839), from Exac 3 at $130 \mathrm{~m}$, UWA133975 (lateral view). fig. 9. Lenticulina pulchella (Reuss, 1863), from Exac 3 at 128 m, UWA133976 (lateral view). figs 10-11. Lenticulina saxocretacea Bartenstein, 1954, specimens from Exac 3 at $128 \mathrm{~m}$ : 10, UWA133977 (lateral view); 11, UWA133978 (lateral view). fig. 12. Lingulina furcillata Berthelin, 1880, from Yinni 1 at 54.65 m, UWA133979 (lateral view). fig. 13. Lingulonodosaria nodosaria (Reuss, 1863), from Exac 2 at 198 m, UWA133980 (lateral view). fig. 14. Marginulina innaminckae Ludbrook, 1966, from Boologooro 1 at 382.0 m, UWA133981 (lateral view). fig. 15. Marginulinopsis jonesi (Reuss, 1863), from Boologooro 1 at 380.6 m, UWA133982 (lateral view). fig. 16. Marginulinopsis sp., from Exac 3 at 87 m, UWA133983 (lateral view). fig. 17. Nodosaria aspera Reuss, 1845, from Exac 2 at 198 m, UWA133984 (lateral view). fig. 18. Palmula? sp., from Boologooro 1 at 382.0 m, UWA133985 (lateral view). fig. 19. Planularia sp. 1, from Yinni 1 at 57.05 m, UWA133986 (lateral view). fig. 20. Planularia sp. 2, from Yinni 1 at 57.05 m, UWA133987 (lateral view). fig. 21. Planularia sp. 3, from Yinni 1 at $57.05 \mathrm{~m}$, UWA133988 (lateral view). fig. 22. Psilocitharella recta (Reuss, 1863), from Boologooro 1 at 380.6 m, UWA133989 (lateral view). fig. 23. Psilocitharella thoerenensis (Bartenstein \& Brand, 1951), from Boologooro 1 at 380.6 m, UWA133990 (lateral view). fig. 24. Pseudonodosaria humilis (Roemer, 1841), from Exac 2 at 194 m, UWA133991 (lateral view). fig. 25. Pseudonodosaria kirschneri Tappan, 1957, from Exac 2 at 198 m, UWA133992 (lateral view). fig. 26. Pyramidulina flexocarinata (Khan, 1950), from Barrabiddy 1 at 142.7 m, UWA133993 (lateral view). fig. 27. Pyramidulina lamellosocostata (Reuss, 1863), from Yinni 1 at 57.05 m, UWA133994 (lateral view). fig. 28. Pyramidulina prismatica (Reuss, 1860), from Exac 3 at 87 m, UWA133995 (lateral view). fig. 29. Pyramidulina sceptrum (Reuss, 1863), from Exac 3 at $58 \mathrm{~m}$, UWA133996 (lateral view). fig. 30. Pyramidulina sp. 1, from Yinni 1 at $54.65 \mathrm{~m}$, UWA133997 (lateral view). fig. 31. Ramulina sp. A of Belford (1960), from Barrabiddy 1 at $142.7 \mathrm{~m}$, UWA133998 (lateral view). fig. 32. Ramulina sp. A of Haig (1982), from Yinni 1 at $54.65 \mathrm{~m}$, UWA133999 (lateral view). fig. 33. Ramulina sp. 3, from Boologooro 1 at $382.0 \mathrm{~m}$, UWA134000 (lateral view). fig. 34. Saracenaria bononiensis (Berthelin, 1880), from Yinni 1 at 57.05 m, UWA134001 (lateral view). fig. 35. Saracenaria pyramidata (Reuss, 1863), from Boologooro 1 at 382.0 m, UWA134002 (lateral view). 


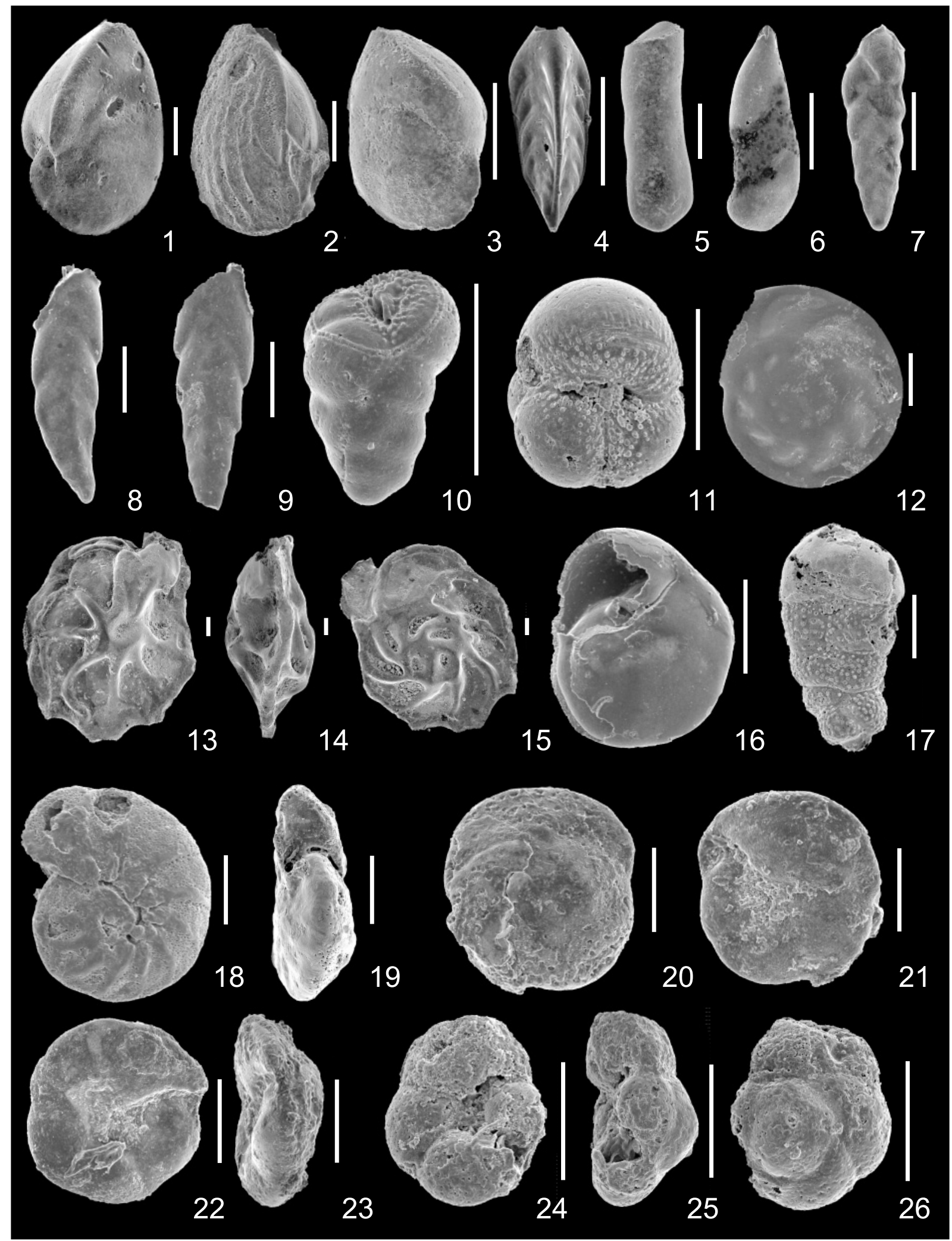




\section{Comparison with bathymetric models derived from other continents}

Based on the palaeoslope model derived by Sikora \& Olsson (1991) for the Upper Albian to Turonian on the Atlantic margin of North America, the Windalia Radiolarite fauna corresponds best to the Epistomina-dominated assemblages from the innermost neritic zone (10-30 m palaeodepth). This is shallower than faunas dominated by species of Berthelina and attributed by Sikora \& Olsson (1991) to the lower inner neritic zone (30-50 m palaeodepth). Koutsoukos \& Hart (1990) working on foraminiferal distributions in the Sergipe Basin of Brazil characterized 'inner to mid shelf' assemblages from the Aptian-Albian by abundant Lingulogavelinella, diverse Lagenida, agglutinated forms including Ammobaculites and calcite-cemented types, and porcellaneous foraminifera. Berthelina dominates the deeper 'middle to outer shelf' assemblages of the Sergipe Basin. The Windalia Radiolarite fauna conforms, in part, to the inner to middle shelf' fauna of Koutsoukos \& Hart (1990). Carrillo et al. (1995) established foraminiferal distributions for the Cretaceous palaeoslope on the northern flank of the Eastern Venezuelan Basin (part of the Atlantic passive margin). Of the biofacies recognized by Carrillo et al. (1995), the fauna from the Windalia Radiolarite corresponds to the inner neritic fauna of organic-cemented agglutinated species (e.g. Haplophragmoides, Ammobaculites) associated with some calcareous species. The mid-neritic fauna of the Eastern Venezuelan Basin is a mixed agglutinated and calcareous-hyaline assemblage including Cibicides $(=$ ?Berthelina $)$ associated with planktonic foraminifera and calcareous nannofossils.

The well-known Albian foraminiferal fauna from the Gault Clay of southern England (Chapman 1891, 1892a, b, 1893, 1894a-c, 1896a, b, 1898; Khan, 1950; Hart et al., 1989; Herrero \& Haynes, 1997) includes common planktonic foraminifera and calcite-cemented agglutinated types among the diverse benthic assemblage and is probably a deeper-water fauna than that represented in the Windalia Radiolarite. Knight (1997) noted the presence of gastropods and microborings in shells from the Gault Clay that suggested the presence of sea-floor algae and deposition within the photic zone at depths less than $80 \mathrm{~m}$, or even shallower, considering the turbid clay substrate. Compared to the fauna recorded by Hart et al. (1989) from the Aptian Atherfield Clay in southern England, the Windalia Radiolarite lacks species of Berthelina and has a less diverse and less abundant planktonic assemblage. This suggests that the Windalia Radiolarite may have been deposited at shallower water depths than the Atherfield Clay. Gaspard (1999) recorded a species of the shallow-water brachiopod Lingula from the Lower Greensand of Atherfield, but its co-occurrence with the foraminiferal fauna recorded by Hart et al. (1989) cannot be determined from the cited literature.

\section{Water-depth determination}

Based on the comparisons described above, the Windalia Radiolarite in the Southern Carnarvon Basin was deposited in the inner neritic zone probably at water depths shallower than $40 \mathrm{~m}$ at maximum flooding. This implies a very broad low gradient continental shelf in the study region during the Aptian, which is supported by the lateral continuity of facies and horizontal bedding. Despite Neogene tectonism resulting from plate collision at the Timor margin of the Australian continent to the north, the present coastal plain and continental shelf of the Southern Carnarvon Basin retains a very low topographic gradient. As an example of a large present-day region almost entirely in the inner neritic zone, the Gulf of Carpentaria (Fig. 1) represents a vast shallow epeiric sea on the Australian continent with a maximum water depth of about $60 \mathrm{~m}$.

As discussed earlier in this paper, foraminiferal distributions suggest that, during deposition of the Windalia Radiolarite, water depths increased slightly to the north in the Southern Carnarvon Basin, following a pattern also evident in the underlying Muderong Shale (Taylor \& Haig, 2001). The continental margin to the north of the Southern Carnarvon Basin formed earlier (at 155-158 Ma according to Müller et al., 1998) than that to the west of the basin (at 130-136 Ma according to Müller et al., 1998). The Aptian bathymetric profile from the study region to across the western continental margin is uncertain because of the lack of detailed information along this margin. DSDP Site 263 situated on oceanic crust in the Cuvier Abyssal Plain (Fig. 1) to the west of the margin was considered by Scheibnerová (1974) to contain Aptian or older deposits of the neritic zone $(<100 \mathrm{~m}$ water depth) in the core 5 to core 29 interval. However, revised palynostratigraphy indicates that the Barremian upper part of the dinoflagellate Muderongia australis

\section{Explanation of Plate 3.}

Secondary electron images; bar scale $0.1 \mathrm{~mm}$. fig. 1. Saracenaria triangularis (d'Orbigny, 1840), from Barrabiddy 1 at $142.7 \mathrm{~m}$, UWA134003 (lateral view). fig. 2. Saracenaria sp. 1 of Haig et al. (1996), from Yinni 1 at 57.05 m, UWA134004 (lateral view). fig. 3. Saracenaria sp. 2, from Yinni 1 at 54.56 m, UWA134005 (lateral view). fig. 4. Tristix perelongata (Ludbrook, 1966), from Exac 3 at 122 m, UWA134006 (lateral view). fig. 5. Vaginulinopsis arimensis (Ludbrook, 1966), from Yinni 1 at $57.05 \mathrm{~m}$, UWA134007 (lateral view). fig. 6. Vaginulinopsis sp., from Barrabiddy 1 at 142.7 m, UWA134008 (lateral view), fig. 7. Cassidella tegulata (Reuss, 1845), from Exac 2 at 200 m, UWA134009 (lateral view). figs 8-9. Coryphostoma sp. of Haig et al. (1996): 8, from Exac 3 at 122 m, UWA134010 (lateral view); 9, from Exac 2 at 130 m, UWA134011 (lateral view). fig. 10. Turrilina? hergottensis (Ludbrook, 1966), from Yinni 1 at $57.05 \mathrm{~m}$, UWA134012 (lateral view). fig. 11. Turrilina? moorei (Haig, 1982), from Barrabiddy 1 at 142.7 m, UWA134013 (umbilical view). fig. 12. Epistomina chapmani ten Dam, 1948, from Exac 3 at 130 m, UWA134014 (lateral view). figs 13-15. Epistomina polypioides Eichenberg, 1933, from Barrabiddy 1 at 142.7 m, UWA134015: 13, 'umbilical view'; 14, peripheral view; 15, 'spiral view'. fig. 16. Reinholdella sp., from Exac 3 at 130 m, UWA134016 (umbilical view). fig. 17. Stedumia lindertensis Bertram \& Kemper, 1982 , from Barrabiddy 1 at 142.7 m, UWA134017 (lateral view). figs 18-19. Berthelina sp., from Boologooro 1 at 382.0 m, UWA134018: 18, umbilical view; 19, peripheral view. figs 20-23. Gavelinella? sp. 1, specimens from Boologooro 1 at 382 m: 20-21, UWA134019 (20, spiral view, 21, umbilical view); 22-23, UWA134020 (22, umbilical view, 23, peripheral view). figs 24-26. Gavelinella? sp. 2, from Barrabiddy 1 at 142.7 m, UWA134021: 24, umbilical view; 25, peripheral view; 26, spiral view. 


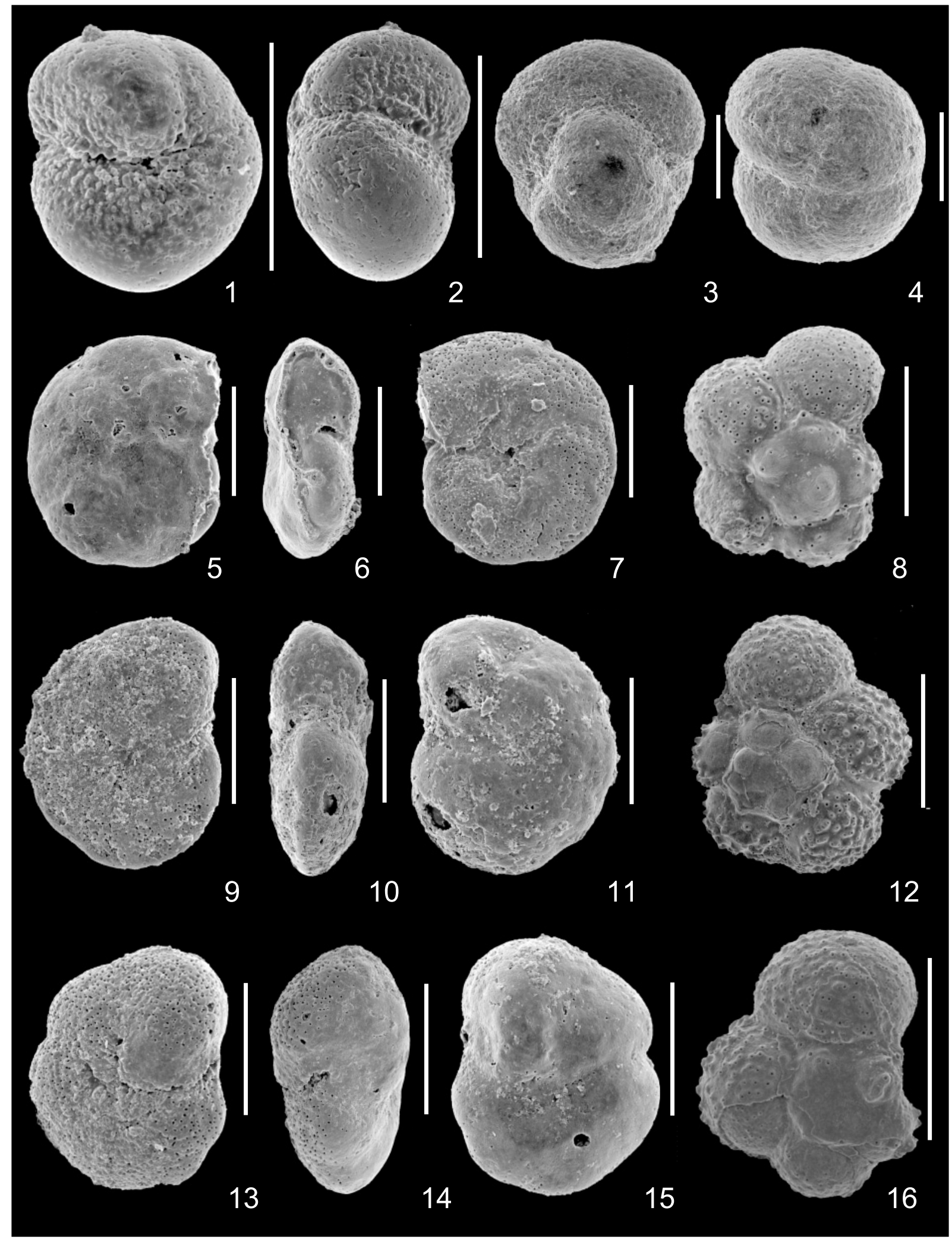




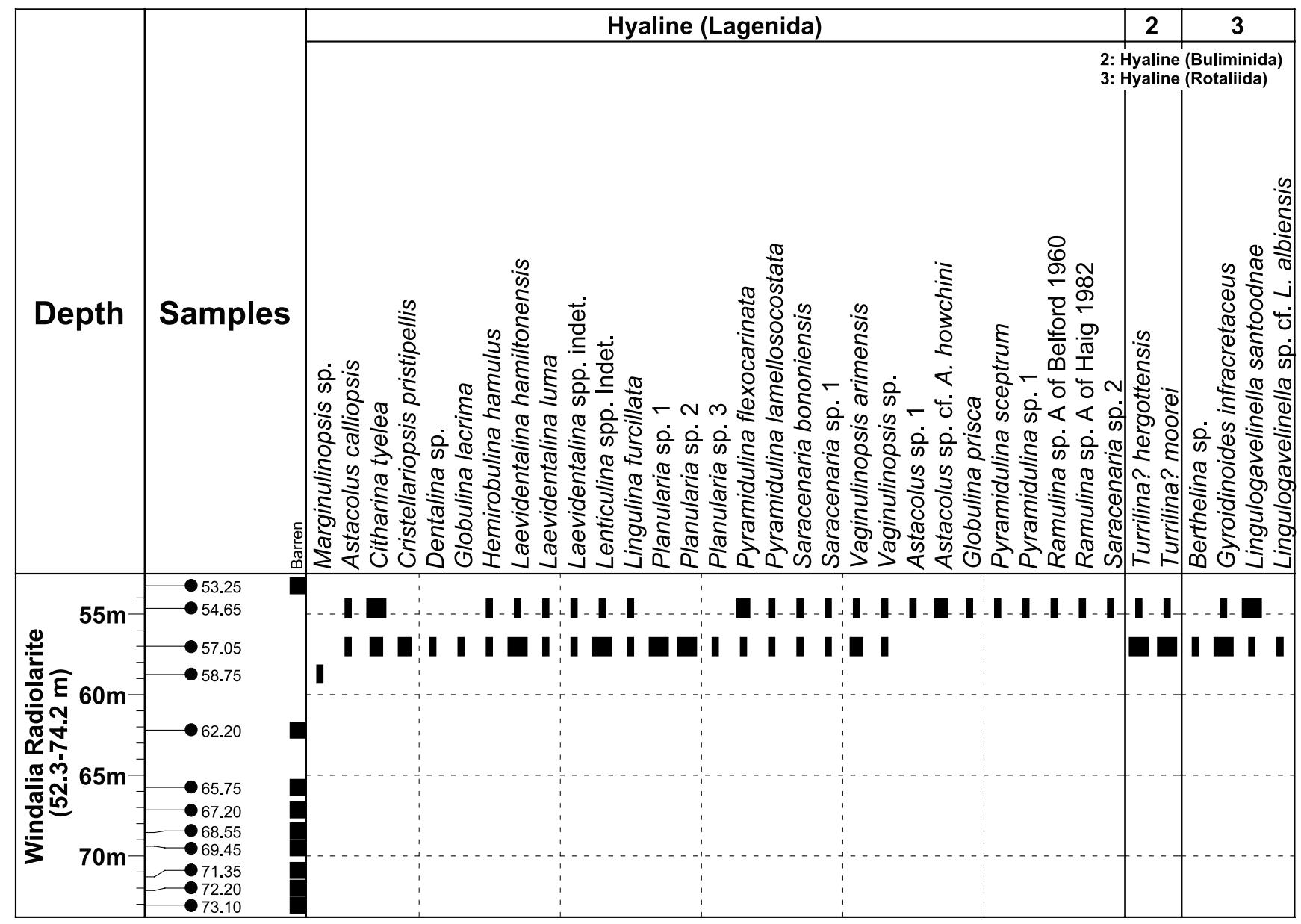

Abundant ( $>20$ specimens) CCommon (10- 20 specimens) |Rare (< 10 specimens)

Fig. 5. Foraminiferal distribution in Yinni 1.

Zone is represented in core 5 and that higher cores contain a mixed palynological record (J. Backhouse pers. comm., November 2003). The Barremian fauna at DSDP Site 263 (equivalent in age to that from the Muderong Shale) contains deep-water agglutinated foraminifera, as noted by Holbourn \& Kaminski (1995). The carbonaceous shale of the Windalia Radiolarite and the other Barremian to Cenomanian formations of the Winning Group and the presence of the Ammobaculites Association through most of this interval, suggest deposition in a basin with restricted circulation. Perhaps the continental margin to the west may have been elevated slightly as a result of earlier Cretaceous or contemporaneous volcanic activity along the margin (such as recorded by Symonds et al., 1998).

\section{DISCUSSION AND CONCLUSIONS}

Modern Radiolaria are best known from open-ocean plankton and the derived deep-water ocean-floor pelagites (Anderson, 1983). Modern neritic radiolarians are less well known (e.g. Diester-Haass, 1982; Swanberg \& Bjørklund, 1986; Bjørklund \& Kruglikova, 2003). Racki \& Cordey (2000) reviewed radiolarian palaeoecology and concluded that modern distributional

Explanation of Plate 4.

Secondary electron images; bar scale $0.1 \mathrm{~mm}$. figs 1-2. Gyroidinoides infracretaceus (Morozova, 1948), specimen from Yinni 1 at $57.05 \mathrm{~m}$, UWA134022: 1, umbilical view; 2, peripheral view. figs 3-4. Pullenia? gyroidinaeformis (Moullade, 1966), specimens from Boologooro 1 at 380.6 m: 3, UWA134023 (peripheral view); 4, UWA134024 (lateral view). figs 5-7. Lingulogavelinella sp. cf. L. albiensis Malapris, 1965, specimen from Barrabiddy 1 at 142.7 m, UWA134025: 5, 'spiral' view; 6, peripheral view; 7, 'umbilical' view. figs 9-11. Lingulogavelinella sp. cf. L. albiensis Malapris, 1965, from Barrabiddy 1 at 126.5 m, UWA134026: 9, 'umbilical' view; 10, peripheral view; 11, 'spiral' view. figs 13-15. Lingulogavelinella santoodnae (Ludbrook, 1966), specimen from Barrabiddy 1 at 142.7 m, UWA134027: 13, 'umbilical' view; 14, peripheral view; 15, 'spiral' view. figs 8, 12, 16. Blefuscuiana infracretacea (Glaessner, 1937), spiral views of specimens from Exac 3 at 122 m: 8, UWA134028; 12, UWA134029; 16, UWA134030. 


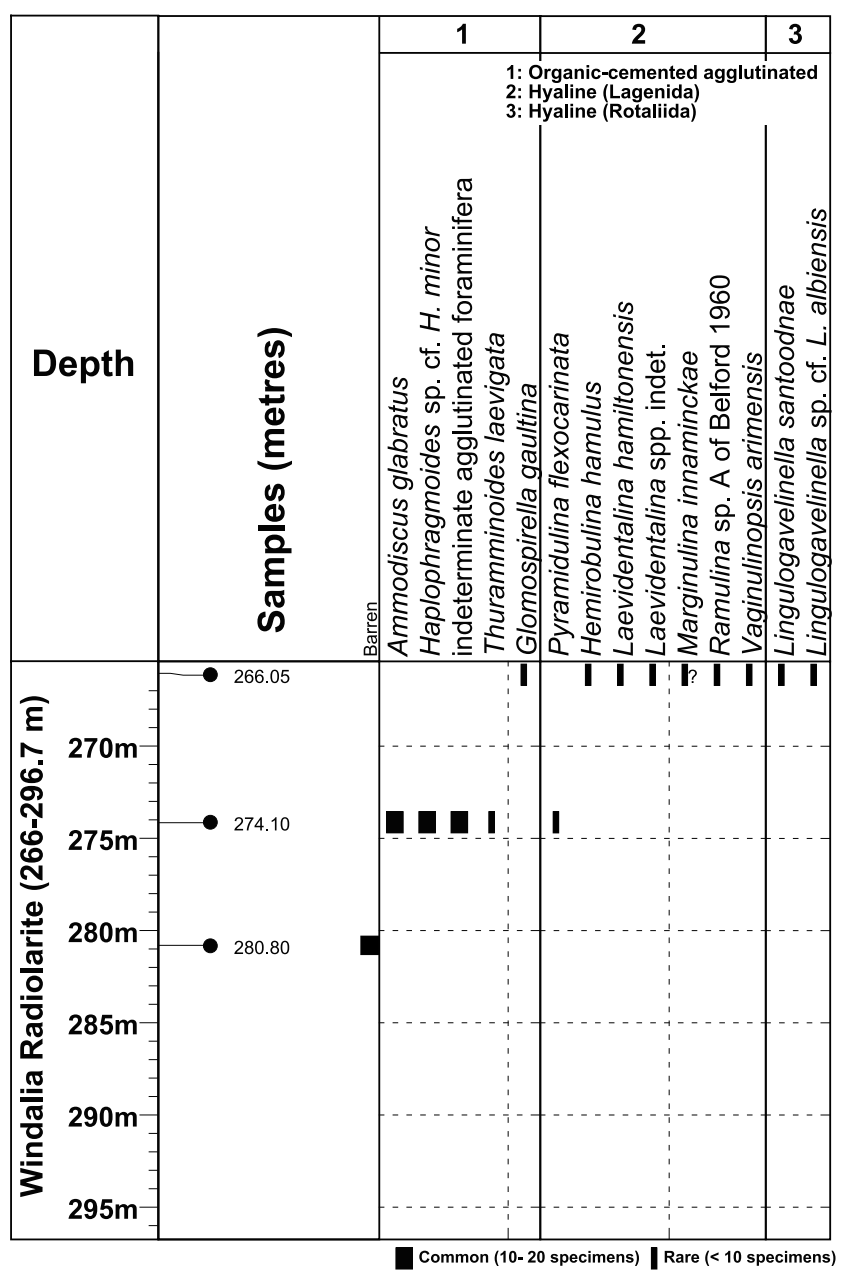

Fig. 6. Foraminiferal distribution in Edaggee 1.

patterns were of limited significance in evaluating the occurrences of pre-Neogene radiolarians, especially from epeiric basins. From independent evidence based on basin setting, foraminiferal assemblages and the presence of Lingula-like brachiopods, the present study demonstrates that, during the Late Aptian, the inner neritic zone in a shelf sea close to the western continental margin of Australia was inhabited by abundant radiolarians. An earlier study by Haig \& Barnbaum (1978) illustrated a diverse radiolarian assemblage from the inner neritic zone in a shallow interior basin (Surat Basin, Fig. 1) far from the open continental margin. The radiolaria in the Australian basins are preserved in organic-rich mudstone successions that suggest high freshwater influx into the basins from a humid vegetated hinterland. It is significant that in western Norwegian fjords, high concentrations of living radiolaria are present in confined highly stratified silled basins and near glacial river mouths (Swanberg \& Bjørklund, 1986). On the west African continental margin, Diester-Haass (1982) recorded radiolaria from sediment at only one site shallower than $500 \mathrm{~m}$; from a river-influenced mud at $63 \mathrm{~m}$ water depth. It seems that radiolaria from Australian Cretaceous basins thrived in very shallow seas where there was high organic influx, in an analogous way to the modern radiolaria recorded by Swanberg \& Bjørklund (1986) and Diester-Haass (1982).

It is apparent, that during the Late Aptian, diverse radiolaria flourished throughout the vast shallow sea that inundated much of the Australian continent under inner neritic depths. At least 59 radiolarian species are present in the Windalia Radiolarite in the Southern Carnarvon Basin (Ellis, 1993) and these are dominated by spumellarians, but include a diverse assemblage of nassellarians. A similar domination by spumellarians is present in the Surat Basin fauna of 41 species recorded by Haig \& Barnbaum (1978). The high diversity and abundance of radiolarians preserved in the organic-rich muds that accumulated in shallow water probably were influenced by high levels of dissolved silica as the sea flooded a mature silicate-rich landscape. During the Aptian, the large volcanic provinces along the eastern and western continental margins may also have contributed to high silica levels in the Australian epeiric sea. Aptian volcanism (Coffin et al., 2002) may have contributed to enhanced dissolved silica levels in the eastern Indian Ocean, as reflected in the presence of cherts in coeval deep-water facies near the continent-ocean margin at ODP Site 766 (Haig, 1992).

From the Barremian to Lower Albian of the Sanfranciscana Basin in Brazil, Pessagno et al. (1997) recorded a 'relatively diverse' radiolarian assemblage in thin chert beds that occur in association with an aeolian, alluvial and lacustrine terrestrial succession. The Brazilian radiolarian-rich cherts may have been deposited in a similar very shallow-water setting to the Windalia Radiolarite.

During the Late Aptian, Australia lay at mid to high palaeolatitudes (Fig. 1), with the Southern Carnarvon Basin close to the northern edge of the continent. Here the surface-water temperatures may have been about $12^{\circ} \mathrm{C}$ (Clarke \& Jenkyns, 1999), whereas, near the southern edge of the Cretaceous continent, almost freezing conditions may have prevailed (Constantine et al., 1998; De Lurio \& Frakes, 1999; Ferguson et al., 1999). A cool humid climate existed over Australia with substantial high-nutrient freshwater input into the epeiric sea, as shown by organic-rich siliciclastic mud facies and the presence of the foraminiferal Ammobaculites Association (Haig, 1979a; Haig \& Lynch, 1993; Campbell \& Haig, 1999; Henderson et al., 2000; Haig, 2004). Price et al. (1998) suggested that intense and frequent storms should occur in Cretaceous mid latitudes during both 'icehouse' and 'greenhouse' intervals. Tempestites have not been recognized in the Windalia Radiolarite or other Cretaceous formations in the Southern Carnarvon Basin.

The foraminiferal fauna from the organic-rich shales of the Windalia Radiolarite includes species of Cassidella (=Fursenkoina of some authors) and Gyroidinoides that characterize eutrophic conditions associated with Aptian-Albian oceanic anoxic events (Erbacher et al., 1998, 1999; Holbourn et al., 2001). In contrast to the open-ocean anoxic facies, the black shales of the Windalia Radiolarite are the result of sedimentation in a very shallow epeiric sea with some restriction in open-marine circulation and eutrophic conditions caused by nutrient-rich freshwater input. Such conditions existed throughout the vast epeiric sea covering the Australian continent during the Aptian, and are characterized by the Ammobaculites Association. 


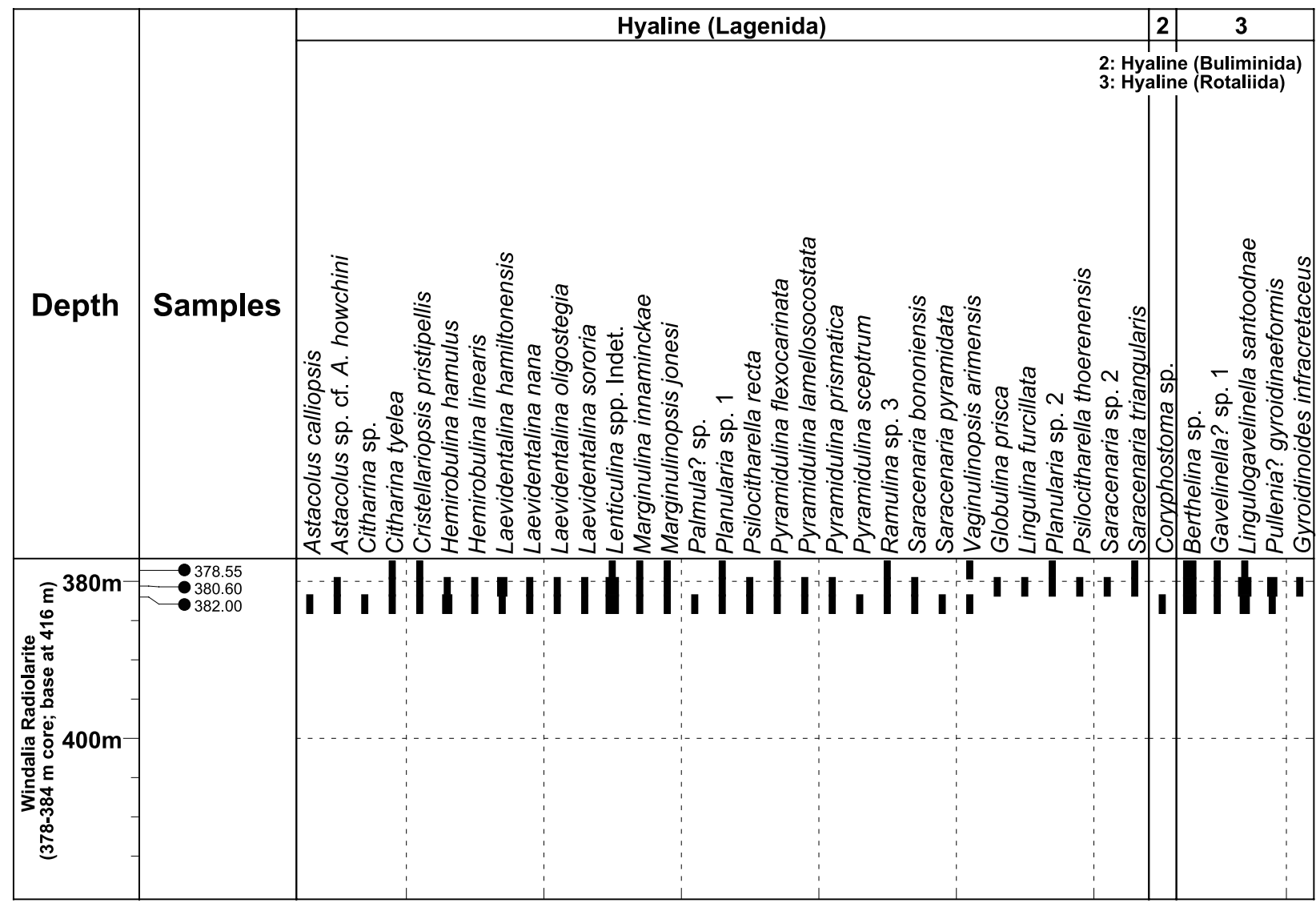

Abundant ( $>20$ specimens) 【Common (10- 20 specimens) IRare ( $<10$ specimens)

Fig. 7. Foraminiferal distribution in Boologooro 1.

During the Late Aptian in the Southern Carnarvon Basin, the Windalia Radiolarite accumulated in cool water at inner-neritic depths probably shallower than $40 \mathrm{~m}$. A slight south-north sea-floor gradient existed in the basin with deeper-water conditions to the north. The organic-rich mudstone, containing Type III kerogens of mainly terrestrial plant origin, indicates eutrophic conditions and restricted marine circulation, and this is reflected also in the benthic foraminiferal assemblage that is characteristic of the Ammobaculites Association. The widespread presence of organic-rich muds through the broad shallow Southern Carnarvon Basin and through the coeval interior basins suggests that regional geomorphology controlled the distribution of eutrophic facies in the Australian Aptian rather than any global expansion of the oxygen minimum zone. The basin conditions may have been influenced by a slightly elevated continental margin to the west, the result of earlier Cretaceous volcanism.

\section{ACKNOWLEDGEMENTS}

This study forms part of Australian Research Council project A00105823. The Geological Survey of Western Australia contributed to this project and allowed access to borehole material. John Backhouse, Arthur Mory, Richard Howe, Marjorie Apthorpe, Robert Campbell, Matt Dixon and Barry Taylor are thanked for many discussions on the Cretaceous biostratigraphy of the Southern Carnarvon Basin. Arthur Mory, Ann Holbourn, John Gregory and an anonymous referee are thanked for reviewing the manuscript and offering valuable suggestions for its improvement. Barry Taylor is thanked for contributing logs of the boresections. Matthew Kuo, Ben Leonard and Ben Hammond prepared the samples for study. Ben Hammond assisted with drafting of the figures and helped with preparation of the manuscript.

\section{LIST OF SPECIES}

Where taxonomic revision has occurred, the original generic designation is given in square brackets.

\section{Agglutinated species}

Ammobaculites humei Nauss, 1947

Ammodiscus glabratus Cushman \& Jarvis, 1928

Bimonilina sp.

Gaudryinella sherlocki Bettenstaedt, 1952

Gaudryinopsis filiformis (Berthelin, 1880) [Gaudryina]

Glomospirella gaultina (Berthelin, 1880) [Ammodiscus]

Haplophragmoides sp. cf. H. minor Nauss, 1947 [6-8 rather than typical 8-11 chambers in final whorl] 


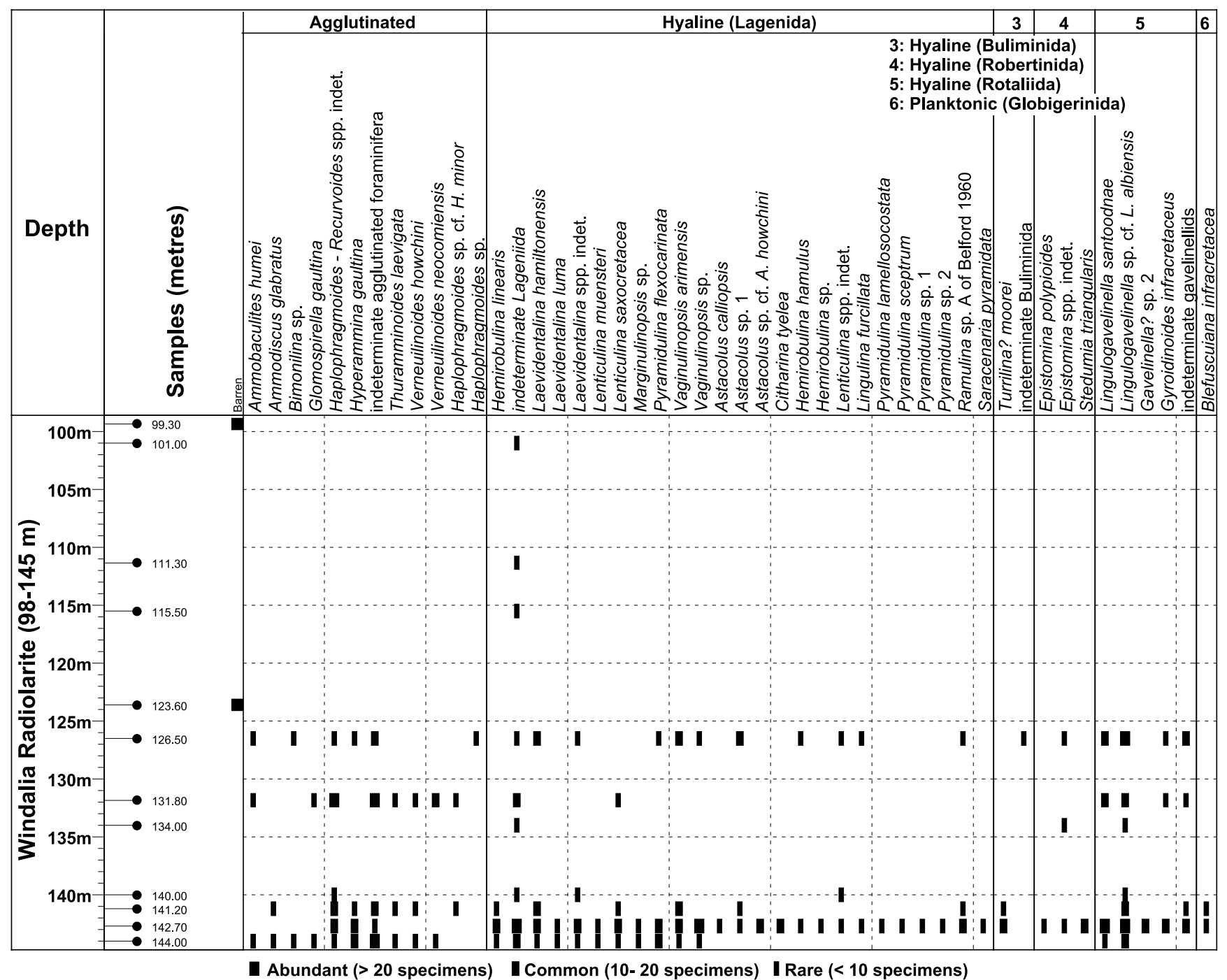

Fig. 8. Foraminiferal distribution in Barrabiddy 1.

Haplophragmoides sp.

Haplophragmoides-Recurvoides spp. indet. [apertures obscured] Hyperammina gaultina ten Dam, 1950

Lagenammina alexanderi (Loeblich \& Tappan, 1950) [Proteonina]

Miliammina ischnia Tappan, 1957

Palustrella sp. [Genus Palustrella Brönnimann, Whittaker \& Zaninetti, 1992; type species Textularia palustris Warren, 1957]

Portatrochammina? sp. [umbilical side crushed; appears to be covered by umbilical flap]

Spiroplectammina edgelli Crespin, 1953

Thuramminoides laevigata White, 1928 [Psammosphaera]

Verneuilinoides howchini (Crespin, 1953) [Verneuilina]

Verneuilinoides neocomiensis (Myatliuk, 1939) [Verneuilina]

Hyaline species (Spirillinida)

Patellinoides tilchus (Ludbrook, 1966) [Hergottella]
Hyaline species (Lagenida)

Astacolus calliopsis (Reuss, 1863) [Cristellaria (Marginulina); lectotype - Meyn \& Vespermann, 1994, pl. 40, figs 16a, b]

Astacolus sp. cf. A. howchini Ludbrook, 1966

Astacolus sp. 1

Brunsvigella debilis (Berthelin, 1880) [Marginulina; Genus Brunsvigella Meyn \& Vespermann, 1994; type species

Vaginulina angustissima Reuss, 1863]

Citharina tyelea Ludbrook, 1966

Citharina sp.

Cristellariopsis pristipellis (Ludbrook, 1966) [Marginulinopsis]

Dentalina sp.

Frondicularia sp. cf. F. filocincta Reuss, 1863 [lacks typical basal ridge and spine on proloculus; see lectotype of $F$. filocincta designated by Meyn \& Vespermann, 1994, pl. 19, fig. 5]

Globulina lacrima Reuss, 1845

Globulina prisca Reuss, 1863 [lectotype - Meyn \& Vespermann, 1994, pl. 61, fig. 6]

Hemirobulina hamulus (Chapman, 1894) [Marginulina] 
Aptian foraminifera from neritic radiolarite

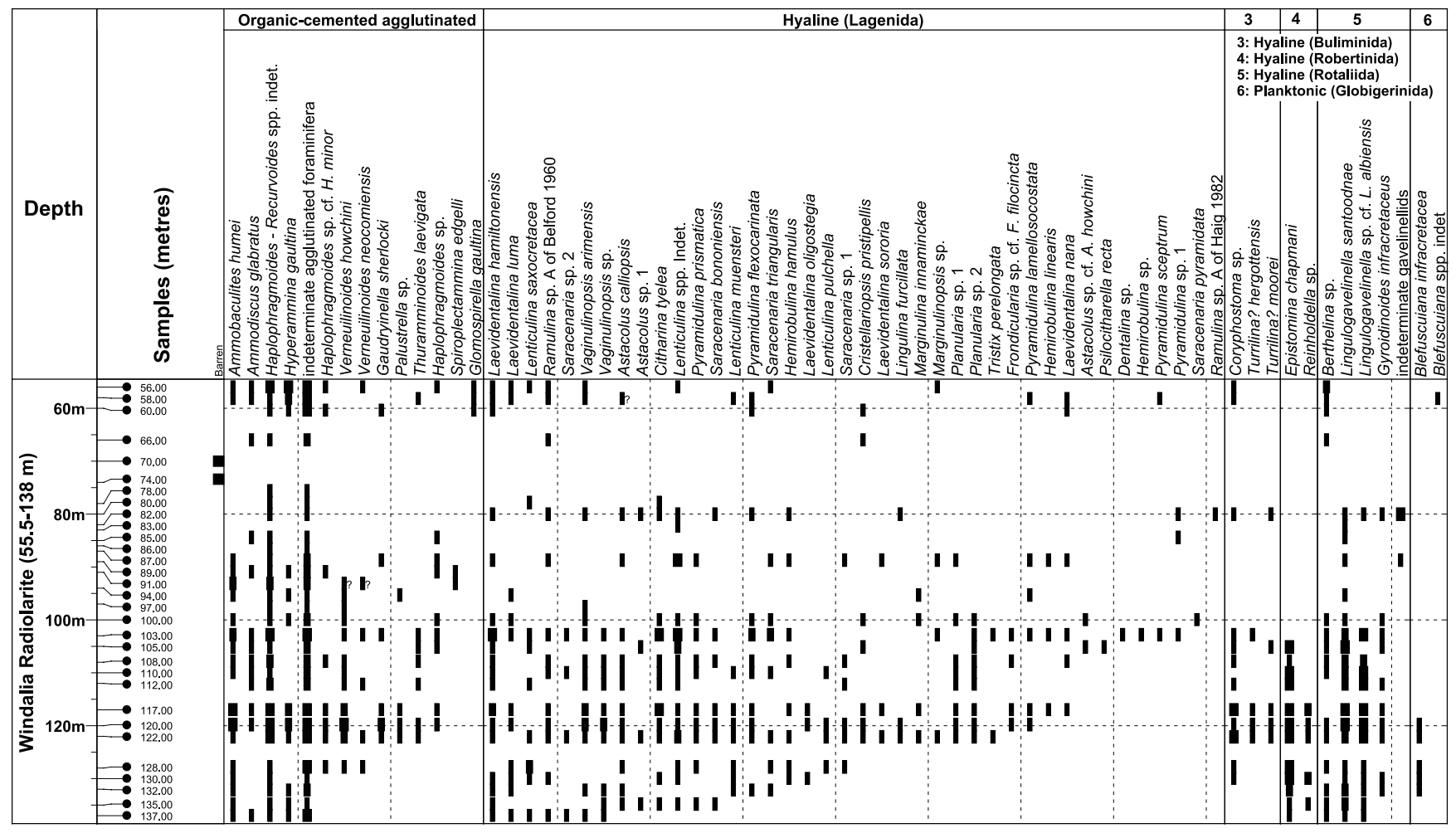

- Abundant ( $>20$ specimens) I Common (10- 20 specimens) IRare $(<10$ specimens)

Fig. 9. Foraminiferal distribution in Exac 3.

Hemirobulina linearis (Reuss, 1863) [Marginulina; lectotype Meyn \& Vespermann, 1994, pl. 44, fig. 2]

Hemirobulina sp.

Laevidentalina hamiltonensis (Ludbrook, 1966) [Dentalina]

Laevidentalina luma (Belford, 1960) [Dentalina]

Laevidentalina oligostegia (Reuss, 1845) [Nodosaria (Dentalina)]

Laevidentalina nana (Reuss, 1863) [Dentalina; lectotype - Meyn \& Vespermann, 1994, pl. 7, fig. 9]

Laevidentalina sororia (Reuss, 1845) [Dentalina]

Lenticulina muensteri (Roemer, 1839) [Robulina; lectotype Meyn \& Vespermann, 1994, pl. 23, figs 14a-c]

Lenticulina pulchella (Reuss, 1863) [Cristellaria; lectotype Meyn \& Vespermann, 1994, pl. 25, figs 5a, b]

Lenticulina saxocretacea Bartenstein, 1954 [lectotype - Meyn \& Vespermann, 1994, pl. 29, fig. 2]

Lingulina furcillata Berthelin, 1880

Lingulonodosaria nodosaria (Reuss, 1863) [Lingulina; lectotype Meyn \& Vespermann, 1994, pl. 5, fig. 9]

Marginulina innaminckae Ludbrook, 1966

Marginulinopsis jonesi (Reuss, 1863) [Marginulina; lectotype Meyn \& Vespermann, 1994, pl. 31, fig. 6]

Marginulinopsis sp.

Nodosaria aspera Reuss, 1845

Palmula? sp.

Planularia sp. 1

Planularia sp. 2

Planularia sp. 3
Psilocitharella recta (Reuss, 1863) [Vaginulina; lectotype - Meyn \& Vespermann, 1994, pl. 59, fig. 2]

Psilocitharella thoerenensis (Bartenstein \& Brand, 1951) [Vaginulina]

Pseudonodosaria humilis (Roemer, 1841) [Nodosaria; neotype Meyn \& Vespermann, 1994, pl. 11, fig. 2]

Pseudonodosaria kirschneri Tappan, 1957

Pyramidulina flexocarinata (Khan, 1950)

Pyramidulina lamellosocostata (Reuss, 1863) [Nodosaria; lectotype - Meyn \& Vespermann, 1994, pl. 16, fig. 2]

Pyramidulina prismatica (Reuss, 1860)

Pyramidulina sceptrum (Reuss, 1863) [Nodosaria (Nodosaria); Neotype - Meyn \& Vespermann, 1994, pl. 12, fig. 9, pl. 13, fig 1].

Pyramidulina sp. 1

Ramulina sp. A of Belford (1960)

Ramulina sp. A of Haig (1982)

Ramulina sp. 3

Saracenaria bononiensis (Berthelin, 1880) [Cristellaria]

Saracenaria pyramidata (Reuss, 1863) [Cristellaria; lectotype Meyn \& Vespermann, 1994, pl. 36, fig. 1]. The species was previously recorded as Saracenaria bronnii (Roemer) by Haig (1981, 1982) and Howe et al. (2000)

Saracenaria triangularis (d'Orbigny, 1840) [Cristellaria]

Saracenaria sp. 1 of Haig et al. (1996)

Saracenaria sp. 2

Tristix perelongata (Ludbrook, 1966) [Tribrachia] 


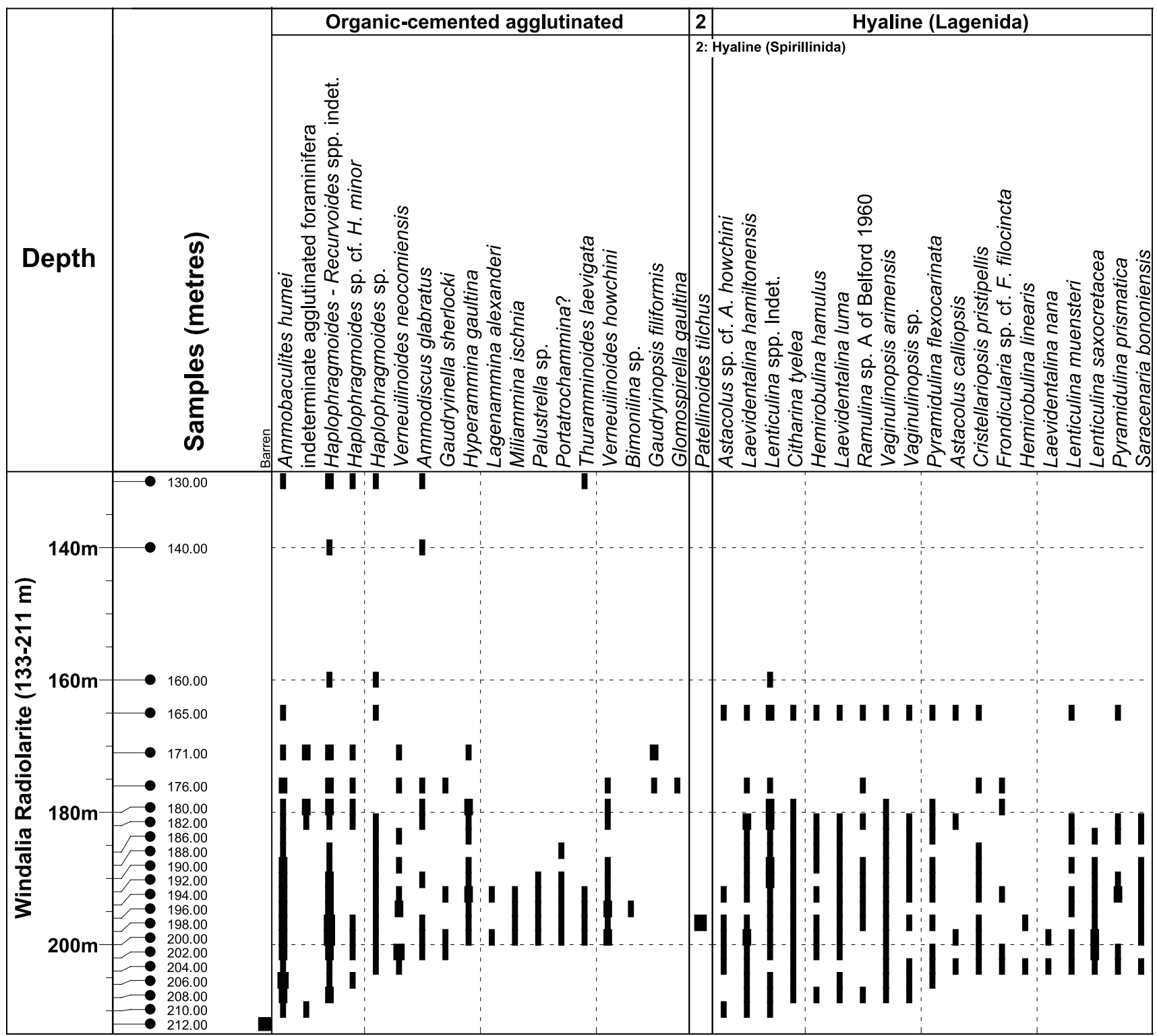

Abundant (> 20 specimens) ICommon (10-20 specimens) IRare ( $<10$ specimens)

Fig. 10.

Vaginulinopsis arimensis (Ludbrook, 1966) [Marginulinopsis] Vaginulinopsis sp.

Hyaline species (Buliminida)

Cassidella tegulata (Reuss, 1845) [Virgulina; considered 'invalid' by Revets (1996) who figured slightly deformed topotypes] Coryphostoma sp. of Haig et al. (1996)

Turrilina? hergottensis (Ludbrook, 1966) [Praebulimina]

Turrilina? moorei (Haig, 1982) [Eurycheilstoma]

Hyaline species (Robertinida)

Epistomina chapmani ten Dam, 1948

Epistomina polypioides Eichenberg, 1933
Reinholdella sp.

Stedumia lindertensis Bertram \& Kemper, 1982

Hyaline species (Rotaliida)

Berthelina sp.

Gavelinella? sp. 1

Gavelinella? sp. 2

Gyroidinoides infracretaceus (Morozova, 1948) [Gyroidina] The record by Haig et al. (1996) is incorrect.

Pullenia? gyroidinaeformis (Moullade, 1966) ['Globigerinelloides']

Lingulogavelinella sp. cf. L. albiensis Malapris, 1965 [has atypical granulate ornament variably developed on 'umbilical' side]

Lingulogavelinella santoodnae (Ludbrook, 1966) [Anomalina] 


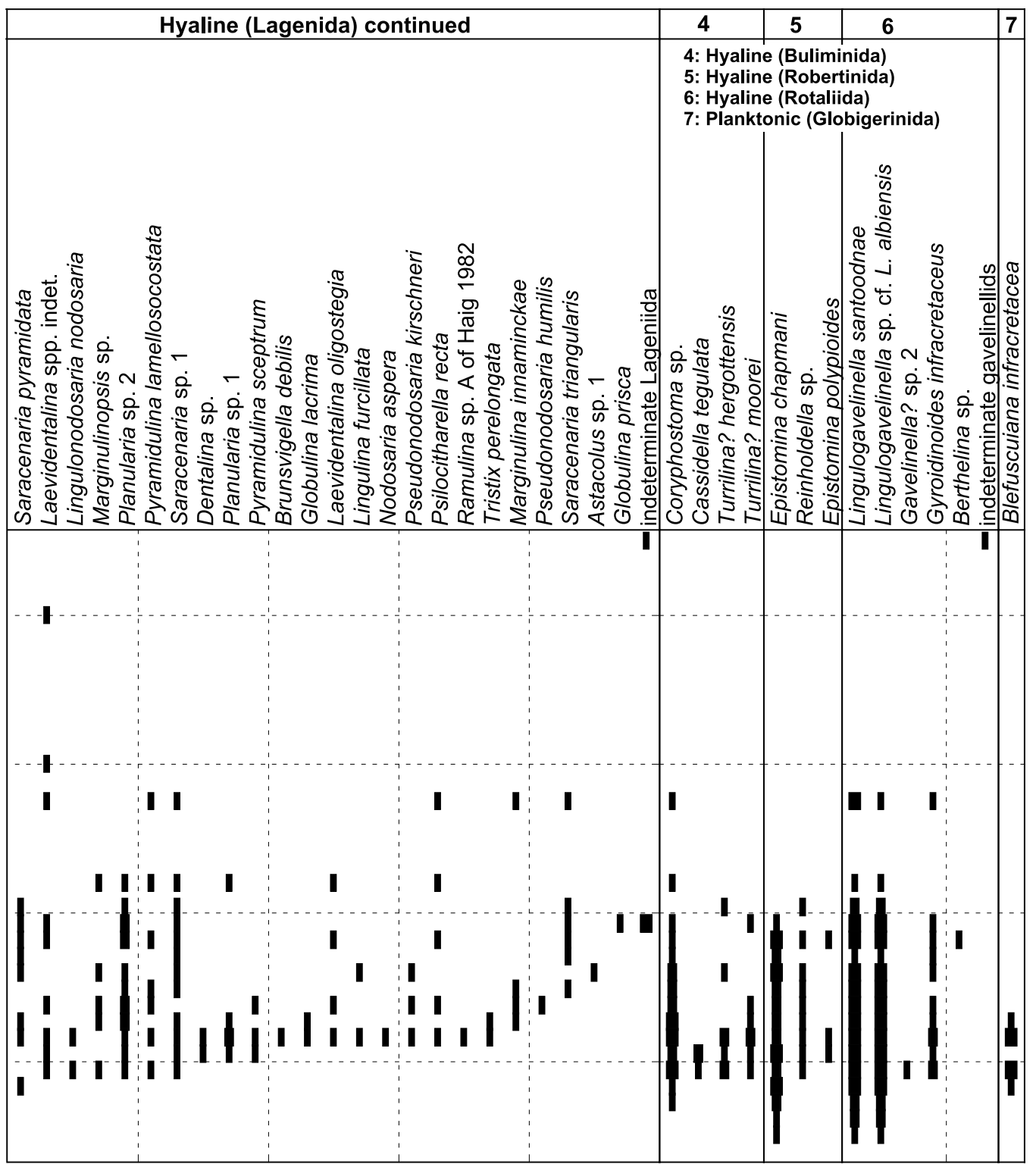

Fig. 10. Foraminiferal distribution in Exac 2.

Hyaline species (Globigerinida)

Blefuscuiana infracretacea (Glaessner, 1937) [Globigerina; following BouDagher-Fadel et al., 1997, placed in Blefuscuiana Banner \& Desai, 1988; type species Blefuscuiana kuznetsovae Banner \& Desai, 1988).

\section{Manuscript received 17 December 2003 \\ Manuscript accepted 6 August 2004}

\section{REFERENCES}

Aguado, R., Castro, J.M., Company, M. \& De Gea, G.A. 1999. Aptian bio-events; an integrated biostratigraphic analysis of the Almadich Formation, inner Prebetic Domain, SE Spain. Cretaceous Research, 20: 663-683.

Anderson, O.R. 1983. Radiolaria. Springer-Verlag, New York, 355pp.

Belford, D.J. 1960. Upper Cretaceous foraminifera from the Toolonga Calcilutite and Gingin Chalk. Western Australia. Australian Bureau of
Mineral Resources, Geology \& Geophysics, Australia, Bulletin, 57: $1-198$.

Bjørklund, K.R. \& Kruglikova, S.B. 2003. Polycystine radiolarians in surface sediments in the Arctic Ocean basins and marginal seas. Marine Micropaleontology, 49: 231-273.

BouDagher-Fadel, M.K., Banner, F.T. \& Whittaker, J.E. 1997. Blefuscuiana, the longest ranging and most diverse of the Praehedbergellidae. In: BouDagher-Fadel, M.K., Banner, F.T. \& Whittaker, J.E. (Eds), The Early Evolutionary History of Planktonic Foraminifera. Chapman \& Hall, London, 121-160.

Bryan, S.E., Constantine, A.E., Stephens, C.J., Ewart, A., Schön, R.W. \& Parianos, J. 1997. Early Cretaceous volcano-sedimentary successions along the eastern Australian continental margin: implications for the break-up of eastern Gondwana. Earth and Planetary Science Letters, 153: 85-102.

Campbell, R.J. \& Haig, D.W. 1999. Bathymetric change during Early Cretaceous intracratonic marine transgression across the northeastern Eromanga Basin, Australia. Cretaceous Research, 20: 403-446. 
Carrillo, M., Paredes, I., Crux, J.A. \& De Cabrera, S. 1995. Aptian to Maastrichtian paleobathymetric reconstruction of the Eastern Venezuelan Basin. Marine Micropaleontology, 26: 405-418.

Chapman, F. 1891. The foraminifera of the Gault of Folkestone (Part1). Journal of the Royal Microscopical Society, 1891: 565-575.

Chapman, F. 1892a. The foraminifera of the Gault of Folkestone (Part 2). Journal of the Royal Microscopical Society, 1892: 319-330.

Chapman, F. 1892b. The foraminifera of the Gault of Folkestone (Part 3). Journal of the Royal Microscopical Society, 1892: 749-758.

Chapman, F. 1893. The foraminifera of the Gault of Folkestone (Part 4). Journal of the Royal Microscopical Society, 1893: 579-595.

Chapman, F. 1894a. The foraminifera of the Gault of Folkestone (Part 5). Journal of the Royal Microscopical Society, 1894: 153-163.

Chapman, F. 1894b. The foraminifera of the Gault of Folkestone (Part 6). Journal of the Royal Microscopical Society, 1894: 421-427.

Chapman, F. 1894c. The foraminifera of the Gault of Folkestone (Part 7). Journal of the Royal Microscopical Society, 1894: 645-654.

Chapman, F. 1896a. The foraminifera of the Gault of Folkestone (Part 8). Journal of the Royal Microscopical Society, 1896: 1-14.

Chapman, F. 1896b. The foraminifera of the Gault of Folkestone (Part 9). Journal of the Royal Microscopical Society, 1896: 581-591.

Chapman, F. 1898. The foraminifera of the Gault of Folkestone (Part 10). Journal of the Royal Microscopical Society, 1898: 1-49.

Clarke, L.J. \& Jenkyns, H.C. 1999. New oxygen isotope evidence for long-term Cretaceous climatic change in the Southern Hemisphere. Geology, 27: 699-702.

Coffin, M.F., Pringle, M.S., Duncan, R.A., Gladczenko, T.P., Storey, M., Müller, R.D. \& Gahagan, L.A. 2002. Kerguelen hotspot magma output since 130 Ma. Journal of Petrology, 43: 1121-1139.

Condon, M.A. 1968. The geology of the Carnarvon Basin. Western Australia. Australian Bureau of Mineral Resources, Geology and Geophysics, Bulletin, 77: 1-68.

Constantine, A., Chinsamy, A., Vickers-Rich, P. \& Rich, T.H. 1998. Periglacial environments and polar dinosaurs. South African Journal of Science, 94: 137-141.

Crespin, I. 1963. Lower Cretaceous arenaceous foraminifera of Australia. Bureau of Mineral Resources, Geology and Geophysics, Bulletin, 66: 1-110.

De Lurio, J.L. \& Frakes, L.A. 1999. Glendonites as a paleoenvironmental tool; implications for Early Cretaceous high latitude climates in Australia. Geochimica et Cosmochimica Acta, 63: 1039-1048.

Diester-Haass, L. 1982. Indicators of water depth in bottom sediments of the continental margin off West Africa. Marine Geology, 49: 311-326.

Dixon, M., Haig, D.W., Mory, A.J., Backhouse, J., Ghori, K.A.R. \& Morris, P.A. 2003a. GSWA Yinni 1 well completion report (interpretive), Gascoyne Platform, Southern Carnarvon Basin, Western Australia. Geological Survey of Western Australia, Record, 2003/7: $1-44$

Dixon, M., Haig, D.W., Mory, A.J., Backhouse, J., Ghori, K.A.R., Howe, R. \& Morris, P.A. 2003b. GSWA Edaggee 1 well completion report (interpretive), Gascoyne Platform, Southern Carnarvon Basin, Western Australia. Geological Survey of Western Australia, Record, 2003/8: $1-80$.

Ellis, G. 1993. Late Aptian-Early Albian radiolaria of the Windalia Radiolarite (type section), Carnarvon Basin, Western Australia. Eclogae Geologicae Helvetiae, 86: 943-995.

Erbacher, J., Gerth, W., Schmiedl, G. \& Hemleben, Ch. 1998. Benthic foraminiferal assemblages of late Aptian-early Albian black shale intervals in the Vocontian Basin, SE France. Cretaceous Research, 19: 805-826.

Erbacher, J., Hemleben, C., Huber, B.T. \& Markey, M. 1999. Correlating environmental changes during early Albian oceanic anoxic event 1B using benthic foraminiferal paleoecology. Marine Micropaleontology, 38: 7-28.

Ferguson, L. 1963. The paleoecology of Lingula squamiformis Phillips during a Scottish Mississippian marine transgression. Journal of Paleontology, 37: 669-681.

Ferguson, K.M., Gregory, R.T. \& Constantine, A. 1999. Lower Cretaceous (Aptian-Albian) secular changes in the oxygen and carbon isotopes record from high paleolatitude, fluvial sediments, southeast Australia: comparison to the marine record. In: Barrera, E.
\& Johnson, C.C. (Eds), Evolution of the Cretaceous Ocean-Climate System. Geological Society of America Special Publication, 332: $59-72$.

Frakes, L.A., Burger, D., Apthorpe, M. et al. 1987. Australian Cretaceous shorelines, stage by stage. Palaeogeography, Palaeoclimatology, Palaeoecology, 59: 31-48.

Gaspard, D. 1999. Distribution of Lower Cretaceous brachiopods in Europe (Berriasian to Aptian). Bulletin de la Société Géologique de France, 170: 311-326.

Gröcke, D.R., Hesselbo, S.P. \& Jenkyns, H.C. 1999. Carbon-isotope composition of Lower Cretaceous fossil wood: ocean-atmosphere chemistry and relation to sea-level change. Geology, 27: 155-158.

Haig, D.W. 1979a. Global distribution patterns for mid-Cretaceous foraminiferids. Journal of Foraminiferal Research, 9: 29-40.

Haig, D.W. 1979b. Cretaceous foraminiferal biostratigraphy of Queensland. Alcheringa, 3: 171-187.

Haig, D.W. 1980. Early Cretaceous textulariine foraminiferids from Queensland. Palaeontographica A, 170: 87-138.

Haig, D.W. 1981. Mid-Cretaceous foraminiferids from the Wahgi Valley, Central Highlands of Papua New Guinea. Micropaleontology, 27: $337-351$.

Haig, D.W. 1982. Early Cretaceous milioline and rotaliine benthic foraminiferids from Queensland. Palaeontographica A, 177: 1-88.

Haig, D.W. 1992. Aptian-Albian foraminifera from Ocean Drilling Program Site 766, Cuvier Abyssal Plain, and comparison with coeval faunas from the Australian region. Proceedings of the Ocean Drilling Program, Scientific Results, 123: 271-297.

Haig, D.W. 2004. Comparison of foraminifera and habitats from Australian Permian and Cretaceous interior seas. Memoir of the Association of Australasian Palaeontologists, 29: 31-46.

Haig, D.W. \& Barnbaum, D. 1978. Early Cretaceous microfossils from the type Wallumbilla Formation, Surat Basin, Queensland. Alcheringa, 2: 159-178.

Haig, D.W. \& Lynch, D.A. 1993. A late early Albian marine transgressive pulse over northeastern Australia, precursor to epeiric basin anoxia: Foraminiferal evidence. Marine Micropaleontology, 22: 311-362.

Haig, D.W., Watkins, D.K. \& Ellis, G. 1996. Mid-Cretaceous calcareous and siliceous microfossils from the basal Gearle Siltstone, Giralia Anticline, Southern Carnarvon Basin. Alcheringa, 20: 41-68.

Haig, D.W., Mory, A.J., Backhouse, J., Campbell, R.J., Ghori, K.A.R., Howe, R. \& Morris, P.A. 2004. GSWA Boologooro 1 well completion report (interpretive), Southern Carnarvon Basin, Western Australia. Geological Survey of Western Australia, Record, 2004/4: $1-106$.

Hardenbol, J., Thierry, J., Farley, M.B., Jacquin, T., De Graciansky, P.C. \& Vail, P.R. 1998. Mesozoic and Cenozoic sequence chronostratigraphy framework of European basins. SEPM Special Publication, 60: 3-14.

Hart, M.B., Bailey, H.W., Crittenden, S., Fletcher, B.N., Price, R.J. \& Swiecicki, A. 1989. Cretaceous. In: Jenkins, D.G. \& Murray, J.W. (Eds), Stratigraphical Atlas of Fossil Foraminifera. Ellis Horwood, London, 273-371.

Henderson, R.A., Crampton, J.S., Dettmann, M.E. et al. 2000. Biogeographical observations on the Cretaceous biota of Australasia. Memoir of the Association of Australasian Palaeontologists, 23: 355-404.

Herrero, C. \& Haynes, J.R. 1997. Revision of the Gault foraminifera from the Hollis and Neaverson collection (1921). Journal of Micropalaeontology, 16: 73-84.

Hocking, R.M., Moors, H.T. \& Van De Graaff, W.J.E. 1987. Geology of the Carnarvon Basin, Western Australia. Geological Survey of Western Australia, Bulletin, 133: 1-289.

Holbourn, A.E.L. \& Kaminski, M.A. 1995. Lower Cretaceous benthic foraminifera from DSDP Site 263: micropalaeontological constraints for the early evolution of the Indian Ocean. Marine Micropaleontology, 26: 425-460.

Holbourn, A.E.L. \& Kaminski, M.A. 1997. Lower Cretaceous deep-water benthic Foraminifera of the Indian Ocean. Grzybowski Foundation Special Publication, 4: 172pp.

Holbourn, A., Kuhnt, W. \& Erbacher, J. 2001. Benthic foraminifers from lower Albian black shales (Site 1049, ODP Leg 171): evidence 
for a non 'uniformitarian' record. Journal of Foraminiferal Research, 31: $60-74$.

Howe, R.W., Haig, D.W. \& Apthorpe, M.C. 2000. CenomanianConiacian transition from siliciclastic to carbonate marine deposition, Giralia Anticline, Southern Carnarvon Platform, Western Australia. Cretaceous Research, 21: 517-551.

Iasky, R.P., Mory, A.J., Ghori, K.A.R. \& Shevchenko, S.I. 1998. Structure and petroleum potential of the southern Merlinleigh SubBasin Carnarvon Basin Western Australia. Geological Survey of Western Australia, Report, 61: 1-63.

Iasky, R.P., D’Ercole, C., Ghori, K.A.R., Mory, A.J. \& Lockwood, A.M. 2003. Structure and petroleum prospectivity of the Gascoyne Platform Western Australia. Geological Survey of Western Australia, Report, 87: 1-56.

Jahren, A.H., Arens, N.C., Sarmiento, G., Guerrero, J. \& Amundson, R. 2001. Terrestrial record of methane hydrate dissociation in the Early Cretaceous. Geology, 29: 159-162.

Jones, C.E. \& Jenkyns, H.C. 2001. Seawater strontium isotopes, oceanic anoxic events, and seafloor hydrothermal activity in the Jurassic and Cretaceous. American Journal of Science, 301: 112-149.

Khan, J. 1950. On some new foraminifera from the Lower Gault of southern England. Journal of the Royal Microscopical Society, 70 268-279.

Knight, R.I. 1997. Benthic palaeoecology of the Gault Clay Formation (Mid- and basal Upper Albian) of the western Anglo-Paris Basin. Proceedings of the Geologists' Association, 108: 81-103.

Koutsoukos, E.A.M. \& Hart, M.B. 1990. Cretaceous foraminiferal morphogroup distribution patterns, palaeocommunities and trophic structures; a case study from the Sergipe Basin, Brazil. Transactions of the Royal Society of Edinburgh: Earth Sciences, 81: 221-246.

Li, Z.X. \& Powell, C.McA. 2001. An outline of the palaeogeographic evolution of the Australasian region since the beginning of the Neoproterozoic. Earth Science Reviews, 53: 237-277.

Ludbrook, N.H. 1966. Cretaceous biostratigraphy of the Great Artesian Basin in South Australia. Geological Survey of South Australia, Bulletin, 40: 1-223.

Meyn, H. \& Vespermann, J. 1994. Taxonomische Revision von Foraminiferen der Unterkreide SE-Niedersachsens nach Roemer (1839, 1841, 1842), Koch (1851) und Reuss (1863). Senckenbergiana lethaea, 74: 49-272.

Mory, A.J. \& Dixon, M. 2002a. GSWA Yinni 1 well completion report (basic data) Gascoyne Platform, Southern Carnarvon Basin, Western Australia. Geological Survey of Western Australia, Record, 2002/6: $1-13$.

Mory, A.J. \& Dixon, M. 2002b. GSWA Boologooro 1 well completion report (basic data) Gascoyne Platform, Southern Carnarvon Basin, Western Australia. Geological Survey of Western Australia, Record, 2002/7: 1-17.

Mory, A.J. \& Dixon, M. 2002c. GSWA Edaggee 1 well completion report (basic data) Gascoyne Platform, Southern Carnarvon Basin, Western Australia. Geological Survey of Western Australia, Record, 2002/8: 1-16.

Mory, A.J. \& Yasin, A.R. 1999. GSWA Barrabiddy 1 and 1a well completion report Wandagee Ridge, Southern Carnarvon Basin, Western Australia. Geological Survey of Western Australia, Record, 1999/3: 1-84.
Müller, R.D., Mihut, D. \& Baldwin, S. 1998. A new kinematic model for the formation and evolution of the west and northwest Australian margin. In: Purcell, P.G. \& Purcell, R.R. (Eds), The Sedimentary Basins of Western Australia 2: Proceedings of the West Australian Basins Symposium Perth, Western Australia, 1998. Petroleum Exploration Society of Australia Limited, Perth, 55-80.

Pessagno, E.A. Jr, Dias, B.D. \& De Castro, J.C. 1997. Tectonostratigraphic significance of radiolarian chert in Lower Cretaceous continental sequence, Minas Gerais, Brazil. Geological Society of America, Abstracts with Programs, 29 (6): 374.

Pirrie, D., Doyle, P., Marshall, J.D. \& Ellis, G. 1995. Cool Cretaceous climates; new data from the Albian of Western Australia. Journal of the Geological Society, London, 152: 739-742.

Price, G.D., Valdes, P.J. \& Sellwood, B.W. 1998. A comparison of GCM simulated Cretaceous 'greenhouse' and 'icehouse' climates; implications for the sedimentary record. Palaeogeography, Palaeoclimatology, Palaeoecology, 142: 123-138.

Racki, G. \& Cordey, F. 2000. Radiolarian palaeoecology and radiolarites: is the present the key to the past? Earth-Science Reviews, 52: $83-120$

Revets, S.A. 1996. The generic revision of five families of Rotaliine foraminifera. Cushman Foundation for Foraminiferal Research, Special Publication, 34: 1-113.

Scheibnerová, V. 1974. Aptian-Albian benthonic foraminifera from DSDP Leg 27, Sites 259, 260 and 263, Eastern Indian Ocean. Initial Reports of the Deep Sea Drilling Project, 27: 697-741.

Scheibnerová, V. 1976. Cretaceous foraminifera of the Great Australian Basin. Memoirs of the Geological Survey of New South Wales, Palaeontology, 17: 1-265.

Sikora, P.J. \& Olsson, R.K. 1991. A paleoslope model of late Albian to Early Turonian foraminifera of the western Atlantic margin and North Atlantic Basin. Marine Micropaleontology, 18: 25-72.

Swanberg, N.R. \& Bjørklund, K.R. 1986. The radiolarian fauna of western Norwegian fjords: Patterns of abundance in the plankton. Marine Micropaleontology, 11: 231-241.

Symonds, P.A., Planke, S., Frey, O. \& Skogseid, J. 1998. Volcanic evolution of the Western Australian continental margin and its implications for basin development. In: Purcell, P.G. \& Purcell, R.R. (Eds), The Sedimentary Basins of Western Australia 2: Proceedings of the West Australian Basins Symposium Perth, Western Australia, 1998. Petroleum Exploration Society of Australia Limited, Perth, 33-54.

Taylor, B.A. \& Haig, D.W. 2001. Barremian foraminifera from the Muderong Shale, oldest marine sequence in the Cretaceous Southern Carnarvon Basin, Western Australia. Micropaleontology, 47: 125-143.

Tyson, R.V. 1987. The genesis and palynofacies characteristics of marine petroleum source rocks. In: Brooks, J. \& Fleet, A.J. (Eds), Marine Petroleum Source Rocks. Blackwell Scientific Publications, Oxford, 47-67.

Veevers, J.J., Powell, C.McA. \& Roots, S.R. 1991. Review of seafloor spreading around Australia. 1: Synthesis of the patterns of spreading. Australian Journal of Earth Science, 38: 373-389.

Weissert, H., Lini, A., Foellmi, K.B. \& Kuhn, O. 1998. Correlation of Early Cretaceous carbon isotope stratigraphy and platform drowning events; a possible link? Palaeogeography, Palaeoclimatology, Palaeoecology, 137: 189-203 